\title{
Airborne measurements of fire emission factors for African biomass burning sampled during the MOYA campaign
}

\author{
Patrick A. Barker ${ }^{1}$, Grant Allen ${ }^{1}$, Martin Gallagher ${ }^{1}$, Joseph R. Pitt ${ }^{2}$, Rebecca E. Fisher ${ }^{3}$, Thomas Bannan ${ }^{1}$, \\ Euan G. Nisbet ${ }^{3}$, Stéphane J.-B. Bauguitte ${ }^{4}$, Dominika Pasternak ${ }^{5}$, Samuel Cliff ${ }^{5}$, Marina B. Schimpf ${ }^{6}$, \\ Archit Mehra $^{1}$, Keith N. Bower ${ }^{1}$, James D. Lee ${ }^{5}$, Hugh Coe ${ }^{1}$, and Carl J. Percival ${ }^{7}$ \\ ${ }^{1}$ School of Earth and Environmental Sciences, University of Manchester, Manchester, M13 9PL, UK \\ ${ }^{2}$ School of Marine and Atmospheric Sciences, 145 Endeavour Hall, Stony Brook University, \\ Stony Brook, NY 11794-5000, USA \\ ${ }^{3}$ Department of Earth Sciences, Royal Holloway, University of London, Egham, Surrey, TW20 0EX, UK \\ ${ }^{4}$ FAAM Airborne Laboratory, National Centre for Atmospheric Sciences, Building 146, \\ College Road, Cranfield, MK43 OAL, UK \\ ${ }^{5}$ Wolfson Atmospheric Chemistry Laboratories, Department of Chemistry, University of York, \\ Heslington, York YO10 5DD, UK \\ ${ }^{6}$ German Aerospace Center (DLR), Flight Experiments, Instrumentation and Data Science, \\ Muenchener Strasse 20, 82234 Weßling, Germany \\ ${ }^{7}$ Jet Propulsion Laboratory, California Institute of Technology, 4800 Oak Grove Drive, \\ M/S 183-901, Pasadena, California 91109, USA
}

Correspondence: Patrick A. Barker (patrick.barker@manchester.ac.uk)

Received: 8 June 2020 - Discussion started: 10 July 2020

Revised: 9 October 2020 - Accepted: 2 November 2020 - Published: 11 December 2020

\begin{abstract}
Airborne sampling of methane $\left(\mathrm{CH}_{4}\right)$, carbon dioxide $\left(\mathrm{CO}_{2}\right)$, carbon monoxide $(\mathrm{CO})$, and nitrous oxide $\left(\mathrm{N}_{2} \mathrm{O}\right)$ mole fractions was conducted during field campaigns targeting fires over Senegal in February and March 2017 and Uganda in January 2019. The majority of fire plumes sampled were close to or directly over burning vegetation, with the exception of two longer-range flights over the West African Atlantic seaboard (100-300 km from source), where the continental outflow of biomass burning emissions from a wider area of West Africa was sampled. Fire emission factors (EFs) and modified combustion efficiencies (MCEs) were estimated from the enhancements in measured mole fractions. For the Senegalese fires, mean EFs and corresponding uncertainties in units of gram per kilogram of dry fuel were $1.8 \pm$ 0.19 for $\mathrm{CH}_{4}, 1633 \pm 171.4$ for $\mathrm{CO}_{2}$, and $67 \pm 7.4$ for $\mathrm{CO}$, with a mean MCE of $0.94 \pm 0.005$. For the Ugandan fires, mean EFs were $3.1 \pm 0.35$ for $\mathrm{CH}_{4}, 1610 \pm 169.7$ for $\mathrm{CO}_{2}$, and $78 \pm 8.9$ for $\mathrm{CO}$, with a mean modified combustion efficiency of $0.93 \pm 0.004$. A mean $\mathrm{N}_{2} \mathrm{O}$ EF of $0.08 \pm 0.002 \mathrm{~g} \mathrm{~kg}^{-1}$ is also reported for one flight over Uganda; issues with temper-
\end{abstract}

ature control of the instrument optical bench prevented $\mathrm{N}_{2} \mathrm{O}$ EFs from being obtained for other flights over Uganda. This study has provided new datasets of African biomass burning EFs and MCEs for two distinct study regions, in which both have been studied little by aircraft measurement previously. These results highlight the important intracontinental variability of biomass burning trace gas emissions and can be used to better constrain future biomass burning emission budgets. More generally, these results highlight the importance of regional and fuel-type variability when attempting to spatially scale biomass burning emissions. Further work to constrain EFs at more local scales and for more specific (and quantifiable) fuel types will serve to improve global estimates of biomass burning emissions of climate-relevant gases. 


\section{Introduction}

The atmospheric burdens of the greenhouse gases (GHGs) $\mathrm{CO}_{2}, \mathrm{CH}_{4}$, and $\mathrm{N}_{2} \mathrm{O}$ have been increasing since the onset of the Industrial Revolution. It is widely accepted that this increase is driven by anthropogenic emissions arising from rapid industrialization and socio-economic development (Montzka et al., 2011; Ciais et al., 2013). However, there is significant uncertainty about the budgets of these greenhouse gases, as their sources and sinks, both natural and anthropogenic, remain poorly constrained. In particular, the continued growth in atmospheric methane since a period of stagnation from 1999-2006, alongside the concurrent shift in ${ }^{13} \mathrm{CH}_{4} /{ }^{12} \mathrm{CH}_{4}$ isotopic ratio, has yet to be accounted for (Nisbet et al., 2016, 2019; Turner et al., 2019; Schaefer, 2019). In order to accurately attribute the causes of the growth in greenhouse gas burdens, whether from increased sources or reduced sinks, all emission sources need to be quantified with accuracy and precision, and with fine detail in temporal and spatial variability.

Biomass burning is a major source, known to contribute significantly to the global budgets of many atmospheric trace gases and aerosols. In addition to $\mathrm{CO}_{2}$, incomplete combustion of biomass fuel produces both methane and $\mathrm{CO}$, as well as $\mathrm{N}_{2} \mathrm{O}$. It has been estimated that $1.6-4.1 \mathrm{Pg}$ of $\mathrm{CO}_{2}, 11-$ $53 \mathrm{Tg} \mathrm{CH}_{4}$, and $0.1-0.3 \mathrm{Tg}$ of $\mathrm{N}_{2} \mathrm{O}$ are emitted to the atmosphere annually as a result of biomass burning on a global scale (Crutzen and Andreae, 2016). The contribution of biomass burning to global GHG budgets will likely increase over time due to climate warming and more widespread drought-stress conditions which increase the likelihood and spread of wildfire events (Liu et al., 2014).

It is estimated that Africa accounts for approximately $52 \%$ of all biomass burning carbon emissions, with the northern sub-Saharan African region alone accounting for 20\%-25\% of global biomass burning carbon emissions (van der Werf et al., 2010; Ichoku et al., 2016). Many or most of these fires are anthropogenic in origin and are started deliberately for reasons such as clearing land for agricultural use, crop waste burning, management of natural savannah vegetation, or pest control (Andreae, 1991). Other fires may simply be accidental (e.g. cigarette disposal). Anthropogenic fires are typically lit in the winter dry season. Natural fires, lit by lightning, can occur in the first early summer wet season thunderstorms over dry growth from the previous year. Despite the importance of the African contribution to global biomass burning emissions, there are limited in situ studies of African wildfire emissions.

The UK Natural Environment Research Council (NERC) Methane Observations and Yearly Assessments (MOYA) project is focused primarily on closing the global methane budget through new in situ observations and analysis of existing datasets. This is being achieved (in part) through targeted field campaigns to constrain poorly quantified methane sources on local and regional scales, as well as the use of atmospheric chemical transport models, such as GEOSCHEM, to provide global estimates of methane emission trends (Bey et al., 2001; Holmes et al., 2013; Saunois et al., 2016).

This paper presents the results of airborne surveys conducted over regions of Senegal and Uganda with high prevalence of biomass burning events. Two aircraft-based field campaigns, using the UK Facility for Airborne Atmospheric Measurements Atmospheric Research Aircraft (FAAM ARA), were conducted in widely separated parts of northern sub-Saharan Africa as part of the MOYA project. The first was based in Senegal between 27 February 2017 and 3 March 2017, and the second was based in Uganda between 16 and 30 January 2019 (henceforth referred to as MOYAI and MOYA-II for the 2017 and 2019 campaigns respectively).

The primary focus of the Senegal campaign was to study fires in the winter dry season. The focus in the Ugandan campaign, which was carried out in the brief January dry season, was on equatorial wetlands, with the aim of quantifying methane emissions from these sources using regionalscale flux techniques (O'Shea et al., 2014; Heimburger et al., 2017), but the study of fires of opportunity in the savannah of northern Uganda was also a major target. The aircraft campaigns also aimed to provide emission estimates for methane and other trace gas and aerosol species from other sources, including anthropogenic emissions from Kampala.

In particular, emission factors (EFs) for $\mathrm{CH}_{4}, \mathrm{CO}_{2}, \mathrm{~N}_{2} \mathrm{O}$, and $\mathrm{CO}$ can be determined from the enhancement in trace gas mixing ratio observed when a biomass burning plume was intercepted. These EFs were calculated for multiple fires observed in Senegal and Uganda. A comparison is made between these Senegalese and Ugandan EFs, to assess and interpret intracontinental variability. Comparisons are also made between EFs determined in this study and EFs from Andreae (2019), who includes up to 50 studies reporting fire EFs and modified combustion efficiencies from multiple biomass burning types, such as tropical forest burning, savannah and grassland burning, and agricultural residue burning.

\section{Description of flights and experimental methods}

\subsection{MOYA-I: Senegal 2017}

During the first MOYA flying campaign (MOYA-I), four research flights (flight numbers C004, C005, C006, and C007) were conducted using the UK Facility for Airborne Atmospheric Measurement (FAAM) BAe 146-301 Atmospheric Research Aircraft (ARA) to specifically sample fire plumes from biomass burning. The ARA was based in Dakar for the duration of this flying campaign. Near-field biomass burning plumes were sampled in C004 and C005 above the Casamance region of wooded savannah in the south-west of Senegal, and longer-range biomass burning outflow for a 


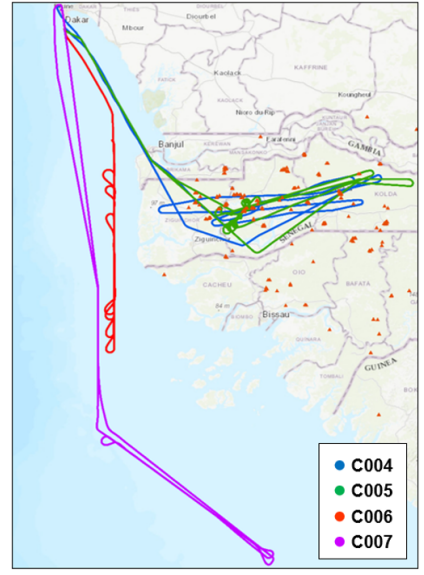

(a)

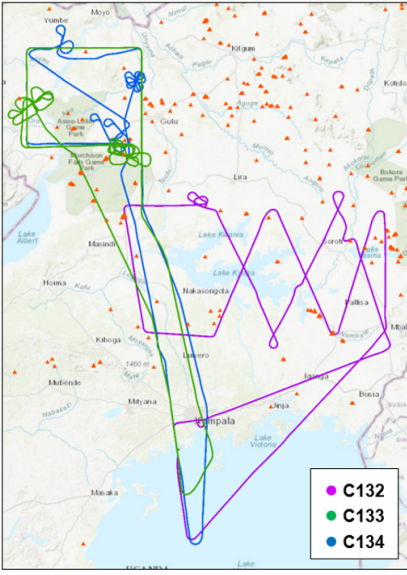

(b)
Figure 1. FAAM ARA flight tracks of (a) MOYA-I biomass burning sampling flights C004 (blue), C005 (green), C006 (red), and C007 (purple) over the south-western region of Senegal and the Atlantic seaboard and (b) MOYA-II biomass burning sampling flights C132 (purple), C133 (green), and C134 (blue) over northern Uganda. MODIS infrared satellite retrievals of fires present between (a) 28 February and 2 March 2017 and (b) 28 and 29 January 2019 are also shown (orange triangles). (C) OpenStreetMap contributors and the GIS user community 2020. Distributed under a Creative Commons BY-SA License.

wider West African region was sampled in C006 and C007 over the Atlantic seaboard.

Figure 1 shows the NASA MODerate Resolution Imaging Spectrometer (MODIS) satellite retrievals of locations that were actively burning during the MOYA-I fire sampling flights, which both took place between 28 February 2017 and 2 March 2017. Several straight and level (constant altitude and heading) runs were made in the central Casamance region of south-west Senegal, to sample nearfield biomass burning emissions from directly above the source fires. Straight and level runs were also carried out during flights $\mathrm{C} 006$ and $\mathrm{C} 007$ but aimed to sample longerrange regional outflow of biomass burning emissions from the wider inland area of interest.

Visual observation during low passes $(<200 \mathrm{~m})$ in the flight showed that the fires were in wooded savannah terrain, in dry winter and brown winter forest tracts. The forests have been described by de Wolf (1998) and by Fredericksen and Lawesson (1992).

The likely fuels were $\mathrm{C}_{3}$ forest leaf litter and dropped branches as well as savannah grass. The Casamance forests in the overflown area were typically low trees with a generally open canopy. A photograph of one of the near-field fires sampled during flight C005 is shown in Fig. 2

\subsection{MOYA-II: Uganda 2019}

The flying campaign in Uganda (MOYA-II) took place in late January 2019, a relatively dry month, when northern Uganda

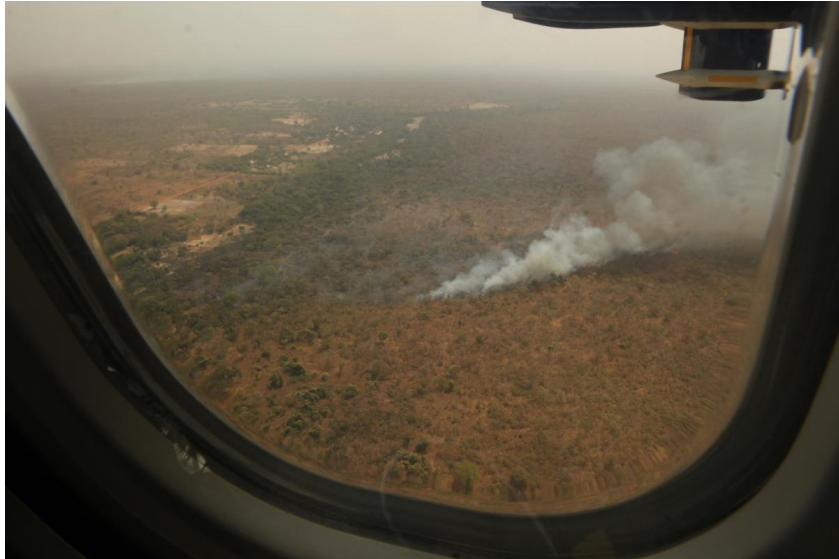

Figure 2. Photograph of Senegalese wildfire taken from aboard the FAAM ARA during flight C005 of the MOYA-I campaign.

experiences its winter dry season, and equatorial southern Uganda is in a short January dry period. The aircraft was based at Entebbe, located on the Equator. Two dedicated biomass burning sampling research flights were conducted (flight numbers C133 conducted on 28 January 2019 and C134 conducted on 29 January 2019), which targeted burning occurring in the north-west of Uganda. Figure 1 shows the flight tracks and MODIS-retrieved fire locations for the MOYA-II flights. The fires were concentrated towards the north of Uganda in this period.

Figure 1 shows both dedicated biomass burning sampling flights (C133 and C134), which focussed on the northwestern corner of Uganda. This region is far enough north (around $3^{\circ} \mathrm{N}$ ) to experience dry season Northern Hemisphere winter. A box pattern was flown around the region, including several passes downwind of fires in the area seen with the clover-like flight patterns.

In addition to these dedicated fire flights, flight C132 (conducted on 28 January 2019) is also included in emission analyses. This flight was over Lake Kyoga, closer to the Equator at about $1.5^{\circ} \mathrm{N}$. The primary purpose of flight $\mathrm{C} 132$ was to survey biogenic methane emissions from Lake Kyoga and the surrounding wetlands. Flight C132 involved straight and level runs across Lake Kyoga. No fires were specifically targeted during this flight but plumes were intercepted from fires over the northern area of Lake Kyoga, as seen by the deviations in the C132 flight path shown in Fig. 1. EFs from these fires are included in this study.

From visual observation, flights $\mathrm{C} 133$ and $\mathrm{C} 134$ likely included fires mainly burning $\mathrm{C}_{4}$ tropical grasses, and on flight C132 the fuel was likely agricultural crop waste, which presumably included $\mathrm{C}_{4}$ maize waste, a major local crop.

\section{3 $\mathrm{CH}_{4}, \mathrm{CO}_{2}, \mathrm{CO}$, and $\mathrm{N}_{2} \mathrm{O}$ instrumentation}

During the MOYA-I and MOYA-II campaigns, the FAAM ARA was equipped with a suite of instrumentation for high- 
accuracy and high-precision trace gas measurement. All airborne trace gas measurements are time synchronized to an on-board time server. For $\mathrm{CH}_{4}$ and $\mathrm{CO}_{2}$ mole fractions, a Los Gatos Research fast greenhouse gas analyser (FGGA) was used. This instrument uses a cavity-enhanced absorption spectroscopy technique and two continuous-wave nearIR diode lasers. A more detailed description of this instrument, along with its modification for airborne measurements, is provided by O'Shea et al. (2013b). The FGGA was calibrated using three calibration gas standards, all of which were traceable to the NOAA/ESRL WMO-X2007 scale for $\mathrm{CO}_{2}$ and the WMO-X2004A scale for $\mathrm{CH}_{4}$. Two of these gas standards provide high- and low-concentration span calibrations that are linearly interpolated over an entire flight in order to account for instrument drift. The remaining gas standard was used as a target to define instrumental measurement uncertainty across multiple flights. During MOYAI the FGGA had a data acquisition rate of $1 \mathrm{~Hz}$, whereas in MOYA-II we used an upgraded system with a $10 \mathrm{~Hz}$ acquisition rate. Accounting for all sources of uncertainty associated with these instruments, the mean biases and associated $1 \sigma$ overall uncertainties are estimated to be $0.004 \pm 0.431 \mathrm{ppm}$ and $0.04 \pm 2.27 \mathrm{ppb}$ for $1 \mathrm{~Hz} \mathrm{CO}_{2}$ and $\mathrm{CH}_{4}$ measurements respectively during MOYA-I and $-0.048 \pm 0.626 \mathrm{ppm}$ and $-1.22 \pm 2.93 \mathrm{ppb}$ respectively for $10 \mathrm{~Hz} \mathrm{CO}_{2}$ and $\mathrm{CH}_{4}$ measurements during MOYA-II, which have been averaged to $1 \mathrm{~Hz}$ prior to analysis.

$\mathrm{N}_{2} \mathrm{O}$ dry-air mole fractions were measured using an Aerodyne quantum cascade laser absorption spectrum (QCLAS) as described by Pitt et al. (2016). This instrument uses a single thermoelectrically cooled quantum cascade laser tuned to a wavelength of $\sim 4.5 \mu \mathrm{m}$. The QCLAS is calibrated using three calibration gas standards, all of which are traceable to the World Meteorological Organization (WMO) X2006 calibration scale for $\mathrm{N}_{2} \mathrm{O}$. A $1 \sigma$ uncertainty of $0.58 \mathrm{ppb}$ was estimated for $1 \mathrm{~Hz} \mathrm{~N}_{2} \mathrm{O}$ mole fraction measurements during the MOYA-II flights. We only report data for the MOYA-II (Uganda) campaign in this study as this instrument was not fitted to the aircraft during the MOYA-I (Senegal) campaign.

The Aerodyne QCLAS $\mathrm{N}_{2} \mathrm{O}$ measurements can be impacted by changes in both cabin pressure and aircraft motion. Changes in altitude and hence cabin pressure change the refractive index in the open path section of the laser beam. This leads to normally static optical fringes moving across the spectral baseline of the instrument, introducing both longterm drift and short-term artefacts into the $\mathrm{N}_{2} \mathrm{O}$ mole fraction data. Sharp changes in aircraft roll angle in tight turns also introduce short-term artefacts as forces acting on optical components cause slight changes in alignment. These issues are described in further detail in Pitt et al. (2016). A further issue encountered solely during the MOYA-II campaign was occasional loss of optical bench temperature control due to the high temperatures experienced within the aircraft during some flights.
Despite these issues, the $\mathrm{N}_{2} \mathrm{O}$ plumes from which $\mathrm{EF}$ could be calculated were sampled at constant altitude with wings level and at constant optical bench temperature. So the instrument issues detailed likely have a minimal influence on data quality during these periods.

Measurements of CO dry-air mole fractions were sampled using an Aero-Laser AL5002 vacuum-UV fast fluorescence instrument. Specifics about the principles of operation for this instrument are provided by Gerbig et al. (1999). The instrument was calibrated in-flight using a gas standard traceable to the NOAA/ESRL WMO-X2014A scale for CO. We have demonstrated that the linear interpolation of in-flight calibrations yields a mean bias $<1 \mathrm{ppb}$ with a $2 \sigma$ precision of $1.8 \mathrm{ppb}$ at $150 \mathrm{ppb}$ for $1 \mathrm{~Hz} \mathrm{CO}$ measurements, when the instrument is operated optimally. However we recently discovered that a faulty inlet drier may have impacted the accuracy of our CO measurements in 2017-2019 and yielded $\mathrm{a}+9 \pm 9 \mathrm{ppb}$ bias in our data. The potential impact of this positive bias is further discussed.

Both the Aero-Laser CO instrument and the FGGA were mounted within the pressurized cabin of the aircraft within a single $48.26 \mathrm{~cm}$ rack. Air was sampled by means of a window-mounted rearward facing inlet comprised of $3 / 8 \mathrm{in}$. PFA tubing housed within $1 / 2$ in. stainless-steel tubing for the $\mathrm{CO}$ inlet and 3/8 in. stainless steel tubing for the FGGA inlet (O'Shea et al., 2013b; Gerbig et al., 1999).

\subsection{HCN and HNCO instrumentation (chemical ionization mass spectrometer)}

The University of Manchester time-of-flight chemical ionization mass spectrometer (ToF-CIMS) that has been described in detail by Priestley et al. (2018a, b) for ground-based deployment has recently been modified and certified for use on the FAAM ARA and was used for real-time detection of hydrogen cyanide (HCN) and isocyanic acid (HNCO) in this study. The instrument and its subsequent modification are described in detail here, as this study presents the first measurements from the modified ToF-CIMS aboard the FAAM ARA. The original instrument was manufactured by Aerodyne Research Inc. and employs the ARI/Tofwerk high-resolution time-of-flight mass spectrometer. Briefly, iodide ions cluster with sample gases, creating a stable adduct that is analysed using time-of-flight mass spectrometry, with an average mass resolution of $4000\left(\mathrm{~m} \Delta \mathrm{m}^{-1}\right)$.

The inlet design was based on the configuration characterized by Le Breton et al. (2014), an atmospheric pressure, rearward-facing, short-residence-time inlet, consisting of a 3/8 in. diameter polytetrafluoroethylene (PTFE) tubing with a total length to the instrument of $48 \mathrm{~cm}$ and based on the design shown in Lee et al. (2018). A constant flow of 12 SLM (standard litres per minute) is mass flow controlled to the ion-molecule reaction region (IMR) using a rotary vane pump (Picolino VTE-3). A total of 1 SLM is then subsampled into the IMR for measurement. An Iris system as de- 
scribed by Lee et al. (2018) was then employed to pressureand mass-flow-control the sample flow into the instrument, avoiding sensitivity changes that would be associated with large variations in pressures in flight that are not controlled sufficiently by the constant flow inlet. This works upon the principle of the manipulation of the size of the critical orifice in response to changes in the IMR pressure. As with the Lee et al. (2018) design, this works by having a stainlesssteel plate with a critical orifice and a movable PTFE plate on top of this, also with a critical orifice. These orifices either align fully and allow maximum flow into the instrument or misalign to reduce flow. This movement is controlled by the 24VDC output of the IMR Pirani pressure gauge in relation to the set point, and the control unit was designed collaboratively with Aerodyne Research Inc. The IMR set point was 80 mbar for the MOYA campaign, which is set through a combination of pumping capacity on the region (Agilent IDP3), mass-flow-controlled reagent ion flow, and sample flow. The reagent ion flow is 1 SLM of ultra-highpurity (UHP) nitrogen mixed with 2 SCCM (standard cubic centimetres per minute) of a pressured known concentration gas mix of $\mathrm{CH}_{3} \mathrm{I}$ in nitrogen, passed through the radioactive source, ${ }^{210} \mathrm{Po}$. The total flow through the IMR is measured (MKS MFM) at the exhaust of the Agilent IDP3 pump so that not only the IMR pressure is monitored but the sample flow also. All mass flow controllers and mass flow meters are measured and controlled using EyeOn. The $1 \sigma$ variability in the IMR pressure during MOYA is $4 \%$ and $6 \%$ in the sample flow.

A standard Aerodyne pressure controller is also employed on the short segmented quadrupole (SSQ) region, with two purposes, easily setting the required pressure during startup but also making subtle adjustments in this region should the IMR pressure change significantly. This works upon the principle controlling an electrically actuated solenoid valve in a feedback loop with the SSQ pressure gauge to actively control a leak of air into the SSQ pumping line. The SSQ is pumped using an Ebara PDV 250 pump and held at $1.8 \mathrm{mbar}$. The $1 \sigma$ variability in the SSQ pressure during MOYA is $<1 \%$.

Instrument backgrounds are programmatically run for $6 \mathrm{~s}$ every minute for the entire flight, by overflowing the inlet at the point of entry into the IMR with UHP nitrogen. Here a 1/16 in. PTFE line enters through the movable PTFE top plate, ensuring that the flow exceeds that of the sample flow. Inlet backgrounds are often run multiple times during flights manually by overflowing as close to the end of the inlet as possible with 20 SLM. Data are taken at $4 \mathrm{~Hz}$ during a flight, which is routinely averaged to $1 \mathrm{~Hz}$ for analysis. Of the six points in each background, the first two and last point are unused and the mean of the background is calculated using custom Python scripting. Using linear interpolation, a time series of the instrument background is determined and humidity is corrected if required and then subtracted to give the final time series of each measured mass. Instrument sensitiv- ity to increased humidity changes influences the sensitivity of the instrument to $\mathrm{HCN}$, and corrections are applied here to correct both the instrumental backgrounds and final time series of $\mathrm{HCN}$ reported here. Only qualitative $\mathrm{HCN}$ and $\mathrm{HNCO}$ data are reported here as quantitative data are not required for the approach of plume identification used in this study.

The CIMS instrument analysis software (ARI Tofware version 3.1.0) was utilized to attain high-resolution $1 \mathrm{~Hz}$ time series of the compounds presented here. For the University of Manchester CIMS, mass-to-charge calibration was performed for five known masses, I-, I-.. $\mathrm{H}_{2} \mathrm{O}$, I-. $\mathrm{HCOOH}, \mathrm{I}_{2}-$, and $\mathrm{I}_{3^{-}}$, covering a mass range of 127 to $381 \mathrm{~m} / \mathrm{z}$. The massto-charge calibration was fitted to a third-order polynomial and was accurate to within $2 \mathrm{ppm}$. $\mathrm{HCN}$ and $\mathrm{HNCO}$ in this case were identified with a $1 \mathrm{ppm}$ error.

\subsection{Whole-air sampling and methane isotopic analysis}

Whole-air samples (WASs) were collected on board the aircraft in 3L silica passivated stainless-steel canisters (Thames Restek, UK). Sample collection was triggered manually to sample within and outside of fire plumes, guided by the realtime methane measurements from the FGGA on board and visual identification of when the plumes were being crossed. Fill times when sampling the fire plumes ranged between 10 and $40 \mathrm{~s}$ depending on sampling altitude, representative of an integrated air sample over a $1-4 \mathrm{~km}$ track. WAS start and end times are recorded using the time on the FAAM ARA onboard time server. Methane mole fraction in the WAS flasks was measured in the Royal Holloway greenhouse gas laboratory using a Picarro 1301 cavity ring-down spectroscopy analyser, and methane isotopic analysis $\left({ }^{13} \mathrm{C}\right)$ was carried out by gas chromatography - isotope ratio mass spectrometry using a trace gas preconcentrator and isoprime mass spectrometer (see Fisher et al., 2006, for details of the technique).

\subsection{Calculation of emission ratios and emission factors}

In order to select when sampled air was influenced by biomass burning emissions, $\mathrm{HCN}$ and $\mathrm{CO}$ were used as biomass burning tracers. HCN was chosen as it is almost exclusively emitted from biomass burning, representing $70 \%$ $85 \%$ of the total global HCN source (Li et al., 2003), and it has a sufficiently long atmospheric lifetime (relative to advection timescales prior to sampling) of 2-4 months, making $\mathrm{HCN}$ a suitable inert tracer for characterizing biomass burning plumes ( $\mathrm{Li}$ et al., 2000).

Like HCN, significant amounts of $\mathrm{CO}$, which has an atmospheric lifetime of 1-3 months (Ehhalt and Prather, 2001), are emitted from biomass burning. $\mathrm{CO}$ is also emitted by vehicles, primarily petrol-fuelled and less so by diesel. However, it is likely that biomass burning is the dominant source of carbonaceous emissions in rural areas of Africa as studied here, whereas vehicular carbon emissions are likely concentrated towards urban centres (Gatari and Boman, 2003). 
HCN was used as a biomass burning tracer for the MOYA-II (Uganda) analysis. However, as the ToF-CIMS was not fitted to the aircraft during the MOYA-I campaign, no HCN measurement is available for this dataset, and hence $\mathrm{CO}$ is used as the biomass burning tracer for MOYA-I analysis.

In order to quantify biomass burning emissions from the enhancements in trace gas mole fraction seen in fire plumes, emission ratios (ERs) and EFs were calculated for each species in each fire plume. In this case, an ER is defined as the ratio of a species $X$ relative to a reference species $Y$. The reference species chosen for this work was CO, as it is relatively inert in the timescale of these measurements, had a relatively stable regional background concentration during these campaigns, and in these rural field areas is almost exclusively emitted during combustion processes and not by other sources such as vehicles (Andreae and Merlet, 2001). The expression for ER calculation is shown in Eq. (1).

$\mathrm{ER}_{\frac{X}{\mathrm{CO}}}=\frac{\Delta X}{\Delta \mathrm{CO}}=\frac{X_{\text {plume }}-X_{\text {background }}}{\mathrm{CO}_{\text {plume }}-\mathrm{CO}_{\text {background }}}$

ERs calculated using this approach are also referred to as normalized excess mixing ratios (NEMRs). When fresh plumes are sampled close to source as they are in the near-field sampling flights, NEMRs can be treated as ERs, calculated using Eq. (1). However in aged plumes, this approach cannot be used to calculate ER, and NEMR is no longer equal to ER. This is due both to chemical processes within the plume that can change composition and to mixing of background air into plume air (Andreae and Merlet, 2001; O'Shea et al., 2013a; Yokelson et al., 2013). HYSPLIT back-trajectory analysis of the MOYA-I far-field flights show that the plume age is $<12 \mathrm{~h}$ for flight C006; hence chemical ageing of biomass burning emissions is unlikely to significantly impact the ER calculation for this flight. Plume ages during flight $\mathrm{C} 007$ are more variable and can exceed $2 \mathrm{~d}$ in some cases, so significant ageing may have occurred. This is discussed in further detail in Sect. 3.2. All near-field flights sample biomass burning emissions at the source, so no significant plume ageing is assumed. Equation (1) can therefore be used to calculate ERs confidently for most flights.

In order to calculate ERs for near-field biomass burning plumes, a baseline mixing ratio $\left(X_{\text {background }}\right)$ was calculated as the average mixing ratio over $10 \mathrm{~s}$ of sampled data to either side of each detected plume. The same baseline data periods chosen for each plume were used for all gas species, to ensure that ERs were comparable and not influenced by inconsistent baseline criteria. Plumes were selected using a statistical method, but the start and the end of each plume as well as the background regions were chosen manually. The area under the plume was then determined by integrating the peak in the concentration vs. time data series, giving a total plume concentration $\left(X_{\text {plume }}\right)$. These values were then used in Eq. (1), along with the corresponding values for $\mathrm{CO}$, to determine an ER. Due to the absence of individual sharp enhancements resolved for specific fire plumes in the far-field flights, a least-squares linear regression of all in-plume points of $X$ vs. in-plume points of CO is used to determine ERs for the far-field flights. The ER is equal to the slope of this linear regression.

Using the calculated ER for each species, EFs were calculated using the carbon mass balance technique (Ward and Hardy, 1984; Radke et al., 1991) An EF is defined as the mass of species emitted (in grams) per kilogram of dry matter burnt. The expression for calculating emission factor is given in Eq. (2).

$\mathrm{EF}_{X}=F_{\mathrm{C}} \cdot 1000\left(\mathrm{~g} \mathrm{~kg}^{-1}\right) \cdot \frac{M_{X}}{M_{\mathrm{c}}} \frac{C_{X}}{C_{\text {total }}}$,

where $F_{\mathrm{C}}$ is the mass fraction of carbon in the dry fuel. A value of 0.475 was assumed in this work to best represent African biomass carbon content, and a $\pm 10 \%$ uncertainty in this value is assumed (Cofer et al., 1996; Ward et al., 1996; Yokelson et al., 2009). $M_{X}$ is the molecular weight of species $X$ and $M_{\mathrm{C}}$ is the atomic mass of carbon-12. The term $\frac{C_{x}}{C_{\text {total }}}$ is the molar ratio of species $X$ to total carbon in the plume, which is calculated using Eq. (3).

$$
\frac{C_{X}}{C_{\text {total }}}=\frac{\mathrm{ER}_{\frac{X}{\mathrm{CO}}}}{1+\frac{\Delta \mathrm{CO}_{2}}{\Delta \mathrm{CO}}+\frac{\Delta \mathrm{CH}_{4}}{\Delta \mathrm{CO}}}
$$

In Eq. (3), total carbon in the fire plume was assumed to be the sum of $\mathrm{CO}, \mathrm{CO}_{2}$, and $\mathrm{CH}_{4}$ emitted. However, as all carbon-containing species could not be measured in this study, the total carbon present in the plume may be underestimated by $1 \%-2 \%$ (as reported by Yokelson et al., 1999).

A statistical threshold approach was used to determine when a biomass burning plume was sampled during flights. For flights where $\mathrm{HCN}$ measurements are available, HCN enhancements exceeding 7 standard deviations above the local background were used to select data for ER and EF calculation. Where HCN was not available during MOYA-I, a $\mathrm{CO}$ threshold of 7 standard deviations over the local background concentration was used. For the far-field flights during MOYA-I (C006 and C007) CO mixing ratios exceeding 15 standard deviations above the local background were chosen for analysis.

\subsection{Modified combustion efficiency}

In addition to EF, the modified combustion efficiency (MCE) is another useful parameter that can be calculated for each biomass burning plume. MCE is here defined by Eq. (4).

$\mathrm{MCE}=\frac{\Delta \mathrm{CO}_{2}}{\Delta \mathrm{CO}_{2}+\Delta \mathrm{CO}}$

MCE can be used to determine the degree to which a fire is smouldering or flaming (Ward and Radke, 1993). Higher MCE values (towards 0.99) indicate that burning is purely flaming, whereas lower MCE values in the range 0.65-0.85 
indicate that smouldering conditions dominate. The proportion of trace gases (such as $\mathrm{CO}$ and $\mathrm{CH}_{4}$ ) emitted typically depends on the completeness of combustion, which is to say that more oxidized products are expected from fires with a high degree of flaming. It is therefore useful to investigate the trend between EF and MCE for different fire plumes (Urbanski, 2013). In the following section, we calculate EFs and MCEs for sampled fire plumes in the MOYA-I and MOYA-II campaigns.

\subsection{Uncertainties}

The standard error of the mean (SE) and the mean measurement uncertainty (MU) are reported for each mean EF and MCE displayed in Table 1. The SE here is determined from all EFs and MCEs calculated for a single flight and represents the variability of EF and MCE within a flight. The MU is propagated from the instrument uncertainties; therefore each $\mathrm{EF}$ and MCE from each fire plume sampled has a measurement uncertainty associated with it. The MUs reported in Table 1 are the average of all individual MUs for all fire plumes sampled during a given flight.

$\mathrm{ER}_{x}$ is calculated using Eq. (1) by subtracting $\mathrm{CO}_{\text {background }}$ from $\mathrm{CO}_{\text {plume }}$; any $\mathrm{CO}$ measurement systematic positive offset would therefore cancel out and not affect the uncertainty of $\mathrm{ER}_{x}$. The detection of $\mathrm{CO}_{\text {plume }}$ during MOYA-I is based on the exceedance of either 7 or 15 standard deviations above background. A CO measurement offset on the background may therefore affect this data filtering step; however due the wide dynamic range of $\mathrm{CO}$ measurements encountered during the plume sampling, we believe a bias will have a very minimal effect on the filtered plume dataset used in our analysis. Similarly, the calculations of $\mathrm{EF}_{x}$ using Eqs. (2) and (3), and MCE using Eq. (4), rely on $\triangle \mathrm{CO}$, which is unaffected by $\mathrm{CO}$ measurement bias as previously stated.

\section{Results and discussion}

In this section, mean EFs and MCEs are reported on a perflight basis, and the differences in relative EFs and MCE between individual flights and between Senegal and Uganda are discussed.

\subsection{Near-field sampling}

\subsubsection{MOYA-I}

Flights C004 and C005. The near-field Senegalese fire sampling flights (flight C004 and C005) were carried out on 28 February and 1 March 2017 respectively. The operating area was over the south-western Casamance region of Senegal. A time series of trace gas mixing ratios $\left(\mathrm{CO}, \mathrm{CH}_{4}\right.$, and $\mathrm{CO}_{2}$ ) during flight $\mathrm{CO04}$ is shown in Fig. 3. An equivalent time series for flight C005 is displayed in the Supplement in Fig. S1.

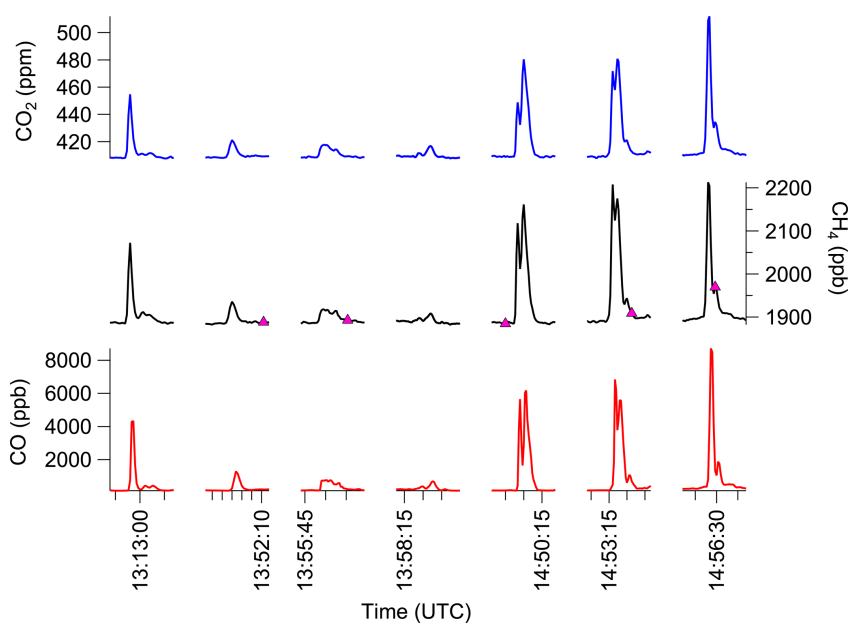

Figure 3. Time series of $\mathrm{CO}$ (red), $\mathrm{CH}_{4}$ (black), $\mathrm{CO}_{2}$ (blue), and concentrations in the plumes analysed for flight C005. Median WAS canister fill times are marked on the $\mathrm{CH}_{4}$ time series as pink triangles. Note that some WASs taken in background regions are not shown here.

The $\delta^{13} \mathrm{C}_{-} \mathrm{CH}_{4}$ isotopic ratio of biomass burning emissions can provide information on the content of the biomass fuel that is burned. In $\mathrm{C}_{4}$ vegetation (e.g. tropical grassland), ${ }^{13} \mathrm{CO}_{2}$ is concentrated during the photosynthetic pathway; hence $\mathrm{C}_{4}$ plants tend to be enriched in ${ }^{13} \mathrm{C}$ and emissions show a higher ${ }^{13} \mathrm{C}_{-} \mathrm{CH}_{4}$ isotopic ratio. $\mathrm{C}_{3}$ vegetation (woody forest) does not involve the same ${ }^{13} \mathrm{C}$ fractionation as $\mathrm{C}_{4}$; therefore emissions show a lower $\delta^{13} \mathrm{C}_{-} \mathrm{CH}_{4}$ ratio relative to $\mathrm{C}_{3}$ plants (Brownlow et al., 2017). Chanton et al. (2000) analysed biomass burning emissions via Keeling plot analysis $\left(\delta^{13} \mathrm{C}-\mathrm{CH}_{4}\right.$ vs. inverse $\mathrm{CH}_{4}$ mole fraction) from a range of fuel sources. They found that African grass burning emitted methane with $\delta^{13} \mathrm{C}_{-} \mathrm{CH}_{4}$ ranging between $-17 \%$ and $-26 \%$, whereas African woodland burning produced methane with a $\delta^{13} \mathrm{C}-\mathrm{CH}_{4}$ ratio of approximately $-30 \%$. For both near-field and far-field MOYA-I flights, whole-air samples were taken of the biomass burning plumes sampled, as well as of the local background. $\delta^{13} \mathrm{C}$ $\mathrm{CH}_{4}$ isotopic ratios and mean $\mathrm{CH}_{4}$ mole fractions are determined from these whole-air samples. Further details of this analysis are provided in Sect. 2.5. Keeling plots for all MOYA-I flights analysed in this work are shown in Fig. 4. Flight $\mathrm{C} 005$ shows a linear relationship between inverse $\mathrm{CH}_{4}$ mole fraction (enhanced $\mathrm{CH}_{4}$ ) and $\delta{ }^{13} \mathrm{C}_{-} \mathrm{CH}_{4}$ signature. This suggests that biomass burning emissions were captured by whole-air sampling during flight $\mathrm{C} 005$. One sample taken during flight $\mathrm{CO04}$ appears to have an enriched $\delta^{13} \mathrm{C}_{-} \mathrm{CH}_{4}$ signal; however this is not included in the linear fit as the single point does not conclusively mean a linear relationship is present. The $Y$ intercept of $-33.7 \pm 1.1 \%$ agrees well with the Chanton et al. (2000) estimate for African forest burning, and suggests that $C_{3}$ vegetation (forest) is included in the fuel burned during flight C005 (Dlugokencky et al., 2011, Chan- 
Table 1. Mean $\mathrm{CH}_{4}, \mathrm{CO}_{2}, \mathrm{~N}_{2} \mathrm{O}$, and $\mathrm{CO}$ EFs and MCE for all MOYA-I (Senegal) and MOYA-II (Uganda) fire sampling flights. Both the standard error on the mean and the mean measurement uncertainty (MU) for EFs and MCEs during each flight for each species are also given. EFs and MCEs compiled from studies of tropical forest and savannah biomass burning by Andreae (2019) are also shown. All EFs are reported in units of grams per kilogram.

\begin{tabular}{|c|c|c|c|c|c|c|c|c|c|c|c|c|c|c|c|c|c|}
\hline & \multirow[b]{2}{*}{ Flight no. } & \multirow[b]{2}{*}{$N$} & \multicolumn{3}{|c|}{$\mathrm{CH}_{4}$} & \multicolumn{3}{|c|}{$\mathrm{CO}_{2}$} & \multicolumn{3}{|c|}{$\mathrm{CO}$} & \multicolumn{3}{|c|}{$\mathrm{N}_{2} \mathrm{O}$} & \multicolumn{3}{|c|}{ MCE } \\
\hline & & & Mean & $\mathrm{SE}$ & MU & Mean & $\mathrm{SE}$ & MU & Mean & SE & MU & mean & SE & MU & Mean & SE & MU \\
\hline \multirow[t]{3}{*}{ MOYA-I } & $\mathrm{C} 004$ & 7 & 2.3 & 0.13 & 0.24 & 1612 & 3.4 & 170 & 84 & 2.3 & 8.7 & - & - & - & 0.93 & 0.0047 & 0.0031 \\
\hline & $\mathrm{C} 005$ & 12 & 1.4 & 0.11 & 0.15 & 1647 & 4.3 & 174 & 61 & 2.9 & 6.2 & - & - & - & 0.95 & 0.0024 & 0.0030 \\
\hline & $\mathrm{C} 007$ & & 2.4 & - & 0.25 & 1663 & - & 173 & - & - & - & - & - & - & 0.96 & - & 0.0037 \\
\hline \multirow[t]{2}{*}{ MOYA-II } & $\mathrm{C} 132$ & 2 & 5.2 & 0.15 & 0.55 & 1554 & 4.0 & 164 & 109 & 2.3 & 11.3 & - & - & - & 0.90 & 0.0021 & 0.0042 \\
\hline & C133 & 11 & 2.8 & 0.21 & 0.30 & 1620 & 7.0 & 171 & 72 & 2.6 & 7.4 & - & - & - & 0.94 & 0.0038 & 0.0041 \\
\hline Andreae (2019) & $\begin{array}{l}\text { Savannah : } \\
\text { grassland }\end{array}$ & & 2.7 & - & 2.2 & 1660 & - & 90 & 69 & - & 20 & 0.17 & - & 0.09 & 0.94 & - & 0.02 \\
\hline
\end{tabular}

a Note that $\mathrm{N}_{2} \mathrm{O}$ EFs could only be calculated for six of the nine fire plumes sampled during flight C134.

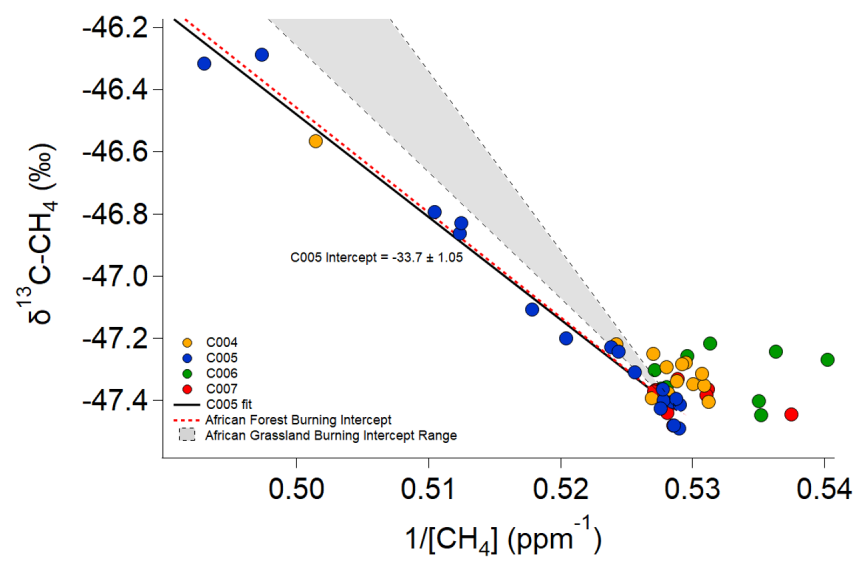

Figure 4. Keeling plot $\left(\delta^{13} \mathrm{C}-\mathrm{CH}_{4}\right.$ vs. inverse $\mathrm{CH}_{4}$ mixing ratio) for all flights in the MOYA-I (Senegal) analyses. A linear fit of points from flight C005 (blue) is also displayed. Simulated fits of African forest (red dashed line) and grassland (grey shaded area) burning using the intercepts and intercept ranges reported by Chanton et al. (2000) are also shown.

ton et al., 2000). Unfortunately, flights over mixed sources in Uganda meant that Keeling plot analysis could not be used to determine the isotopic composition of fire emissions in the same way as carried out for Senegal. The Keeling plot for the MOYA-II isotope samples is shown in the Supplement (Fig. S2)

Table 1 shows the EFs calculated for all species during flights C004 and C005, as well as savannah and grassland and tropical forest fire EFs reported by Andreae (2019). The methane EFs for C004 and C005 (2.3 \pm 0.24 and $1.4 \pm$ $0.15 \mathrm{~g} \mathrm{~kg}^{-1}$ respectively) in this region, at the northern fringe of the African moist tropics, are more comparable to the savannah and grassland methane EFs $\left(2.7 \pm 2.2 \mathrm{~g} \mathrm{~kg}^{-1}\right)$ averaged from multiple previous studies by Andreae (2019). Additionally, mean CO EFs $\left(84 \pm 8.7 \mathrm{~g} \mathrm{~kg}^{-1}\right.$ for C004 and
$61 \pm 6.2 \mathrm{~g} \mathrm{~kg}^{-1}$ for C005) are also more comparable to the savannah and grassland CO EF of $69 \pm 20 \mathrm{~g} \mathrm{~kg}^{-1}$ than the tropical forest CO EF of $104 \pm 39 \mathrm{~g} \mathrm{~kg}^{-1}$ reported by Andreae (2019).

The magnitude of methane EFs can be affected by multiple factors, such as fuel moisture (affecting combustion efficiency) as well as fuel type (Brownlow et al., 2017). It is worth noting that the majority of studies included in the Andreae (2019) tropical forest analysis focus on burning associated with Amazonian deforestation, which consists mostly of broad-leafed evergreen forest. In contrast, the Casamance region consists of facultatively deciduous broad-leafed forested savannah, which was observed from the aircraft and is shown by the land cover map in Fig. 5a. It is thus possible that any forest matter burned during the MOYA-I flights consists of dry leaf-litter fuel, whereas the Andreae (2019) study comprising mostly Amazonian land clearing may have included burning of whole evergreen tree structures. In addition to this, the modified combustion efficiencies of the C004 and C005 fires $(0.93 \pm 0.0031$ and $0.95 \pm 0.0030$ respectively) are both higher than that reported in Andreae (2019) for tropical forest $(0.91 \pm 0.03)$ and are more comparable with the Andreae (2019) MCE for savannah and grassland burning $(0.94 \pm 0.02)$. This is likely due to the lower fuel moisture content of dry leaf-litter and savannah grasses as opposed to Amazonian evergreen; hence the methane EFs are likely driven by combustion efficiency.

From the EF and $\delta^{13} \mathrm{C}_{-} \mathrm{CH}_{4}$ results from flights $\mathrm{C} 004$ and $\mathrm{C} 005$, it is likely that the biomass fuel is a mixture of both deciduous forest matter and savannah grasses as inferred from the isotope and EF results, as well as visual observations of forested savannah and the presence of shrubland and open forest in the land cover classification (Fig. 5a). 
(a)

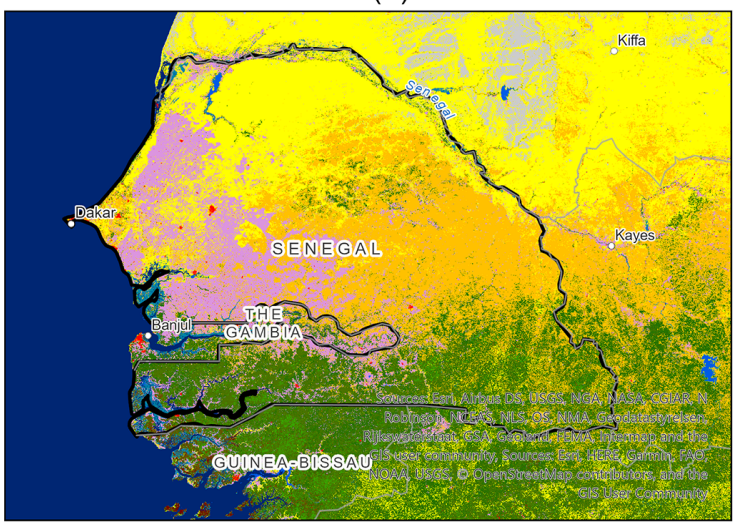

CGLS Land Cover Classification

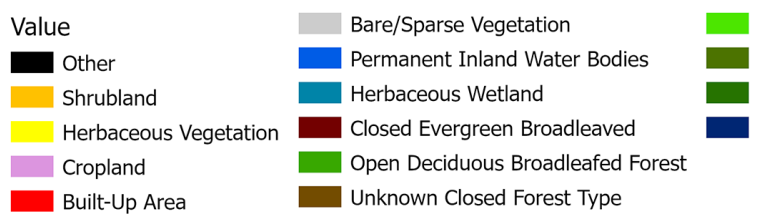

(b)

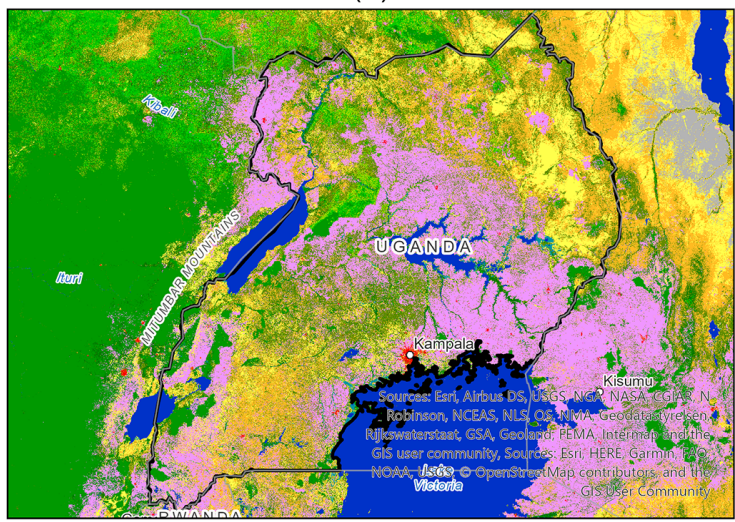

Closed Deciduous Broadleaved Forest

Unknown Open Forest Type

Open Evergreen Forest

Permanent Water Bodies

Figure 5. (a) Land cover classification map of Uganda from 2019. (b) Land cover classification map of Senegal from 2017. Data are obtained from the Copernicus Global Land Service Africa Land Cover Maps, which are derived from PROBA-V satellite observations (Buchhorn et al., 2019). ( ) OpenStreetMap contributors and the GIS user community 2020. Distributed under a Creative Commons BY-SA License.
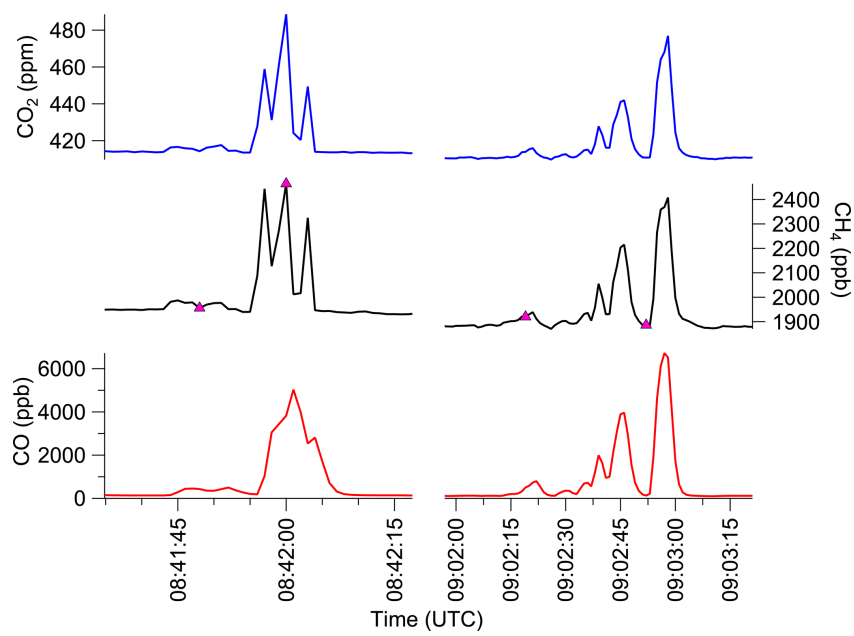

Figure 6. Time series of $\mathrm{CO}$ (red), $\mathrm{CH}_{4}$ (black), $\mathrm{CO}_{2}$ (blue), and concentrations in the plumes analysed for flight C005. Median WAS canister fill times are marked on the $\mathrm{CH}_{4}$ time series as pink triangles. Note that some WASs taken in background regions are not shown here.

\subsubsection{MOYA-II}

Flight C132. Flight C132 was undertaken on 28 January 2019, as a survey of the Lake Kyoga wetland area. Two crop waste biomass burning plumes were sampled from two distinct fires in the area (see Fig. 1). A time series of various trace gas mixing ratios during this flight is shown in Fig. 6 .
As seen in Fig. 6, enhancements (relative to background) in all trace gases were observed in the two biomass burning plumes. However, $\mathrm{N}_{2} \mathrm{O}$ mixing ratio data during the two enhancements were discarded due to aircraft turbulence, which may have corrupted data quality. As a result of the discarded data, as well as instrument drift owing to malfunction of the laser coolant system, $\mathrm{N}_{2} \mathrm{O}$ EFs are not reported for flight C132.

Figure $5 b$ shows the land cover of Uganda where the fire sampling flights were carried out. In agreement with onboard observations from the aircraft, much of the land surrounding Lake Kyoga is classified as cropland, and the fuel for the fires appeared to be primarily crop waste. This is a major farming region, with the main crops including maize (a $\mathrm{C}_{4}$ plant) and cassava $\left(\mathrm{C}_{3}\right)$ south of Lake Kyoga and sorghum $\left(\mathrm{C}_{4}\right)$ north of the lake. (FEWS NET, 2020). The mean EFs calculated for $\mathrm{C} 132\left(5.2 \pm 0.55 \mathrm{~g} \mathrm{~kg}^{-1}\right.$ for $\mathrm{CH}_{4}$, $1554 \pm 164.2 \mathrm{~g} \mathrm{~kg}^{-1}$ for $\mathrm{CO}_{2}$, and $109 \pm 11.3 \mathrm{~g} \mathrm{~kg}^{-1}$ for $\mathrm{CO}$ ) agree within overlapping uncertainty with mean agricultural burning EFs of $5.7 \pm 6.0 \mathrm{~g} \mathrm{~kg}^{-1}$ for $\mathrm{CH}_{4}, 1430 \pm 240 \mathrm{~g} \mathrm{~kg}^{-1}$ for $\mathrm{CO}_{2}$, and $76 \pm 55 \mathrm{~g} \mathrm{~kg}^{-1}$ for $\mathrm{CO}$ reported by Andreae

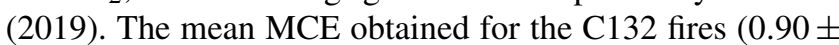
0.0042) is also in agreement with the Andreae (2019) MCE for agricultural residue burning $(0.92 \pm 0.06)$. Furthermore, compared to northern Uganda, the Lake Kyoga region has a shorter dry season and higher rainfall. In addition, the fires were bordering a wetland area. Thus the moister conditions of the Lake Kyoga fires could have resulted in lower tem- 


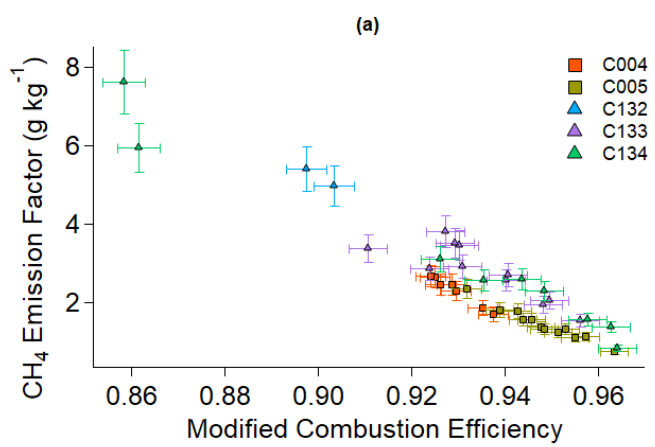

(b)

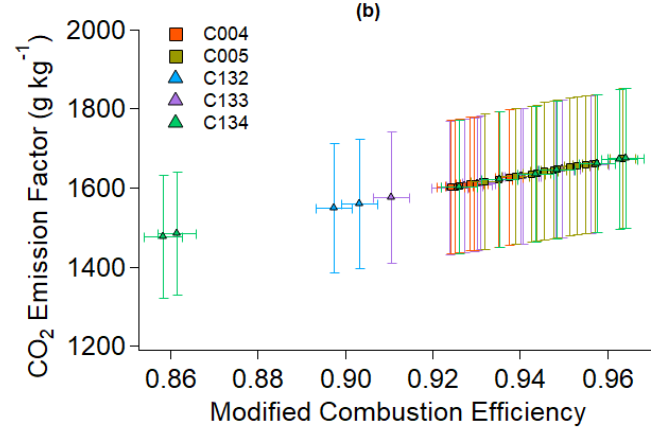

(c)

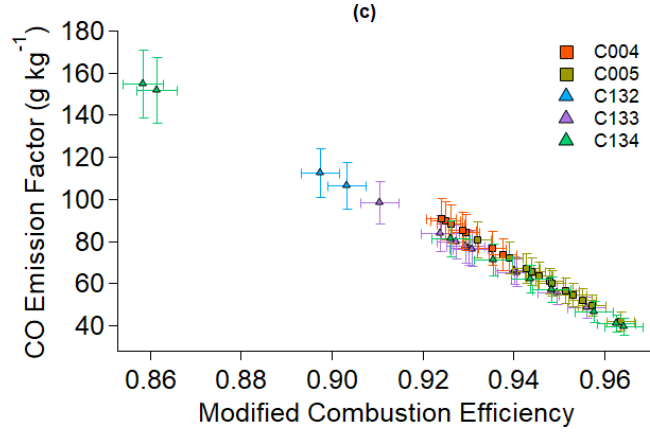

Figure 7. (a) Methane, (b) $\mathrm{CO}_{2}$, and (c) $\mathrm{CO} \mathrm{EF}$ vs. modified combustion efficiency for all biomass burning plumes sampled over all flights (squares are MOYA-I and triangles are MOYA-II). Points are coloured by flight number.

perature, moister combustion, and therefore more incomplete burning.

Flights $\mathrm{C} 133$ and $\mathrm{C} 134$. Flights $\mathrm{C} 133$ and $\mathrm{C} 134$ were dedicated fire sampling flights surveying the winter savannah of north-west Uganda. Both flights involved box patterns flown over this region, with deviations taken in order to sample biomass burning plumes visibly identified over the course of the flights. C133 and C134 were undertaken on 28 and 29 January 2019 respectively. The trace gas time series for these flights are shown in the Supplement in Figs. S3 and S4.

The EFs determined for the fire plumes encountered during flight $\mathrm{C} 133\left(2.8 \pm 0.30\right.$ for $\mathrm{CH}_{4}, 1620 \pm 171.2$ for $\mathrm{CO}_{2}$ and $72 \pm 7.4 \mathrm{~g} \mathrm{~kg}^{-1}$ for $\mathrm{CO}$ ) agreed well with Andreae (2019) savannah burning EFs $\left(2.7 \pm 2.2 \mathrm{~g} \mathrm{~kg}^{-1}\right.$ for $\mathrm{CH}_{4}, 1660 \pm 90 \mathrm{~g} \mathrm{~kg}^{-1}$ for $\mathrm{CO}_{2}$, and $69 \pm 20 \mathrm{~g} \mathrm{~kg}^{-1}$ for $\mathrm{CO}$ ). The mean $\mathrm{CH}_{4}$ and $\mathrm{CO}_{2}$ EFs for $\mathrm{C} 134$ ( $3.1 \pm 0.22$ and $1609 \pm 173.8 \mathrm{~g} \mathrm{~kg}^{-1}$ respectively) are broadly comparable
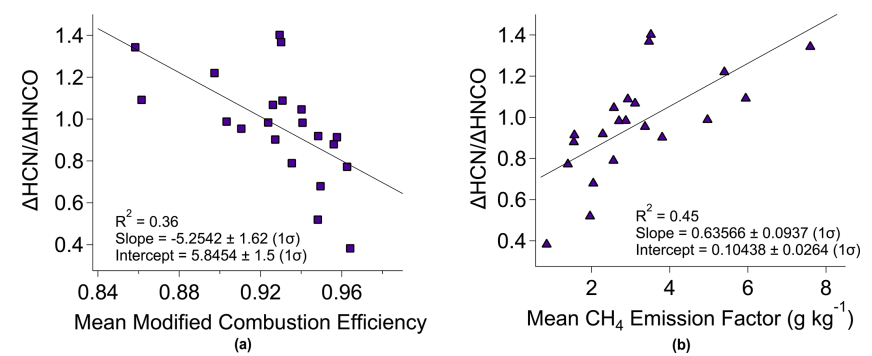

Figure 8. Plot of HCN enhancement over HNCO enhancement in biomass burning plumes vs. (a) mean modified combustion efficiency and (b) mean methane EF in grams per kilogram for all MOYA-II data.

with the $\mathrm{CH}_{4}$ and $\mathrm{CO}_{2} \mathrm{EFs}$ calculated for $\mathrm{C} 133$. Additionally, the mean MCE for $\mathrm{C} 134(0.93 \pm 0.0042)$ is comparable to that of $\mathrm{C} 133(0.94 \pm 0.0041)$. The mean MCEs for C133 and $\mathrm{C} 134$ demonstrate that the burning observed in these flights was characterized by more complete flaming combustion than that observed in flight $\mathrm{C} 132(0.90 \pm 0.0042)$, resulting in the comparatively higher $\mathrm{CO}_{2} \mathrm{EFs}$ and lower $\mathrm{CH}_{4} \mathrm{EFs}$ determined for $\mathrm{C} 133$ and $\mathrm{C} 134$ relative to $\mathrm{C} 132$. The trends in mean MCE and EFs observed during C132, C133, and C134 suggest that EFs are mostly determined by the completeness of combustion over other factors, which is illustrated by the linear relationships between $\mathrm{CH}_{4}, \mathrm{CO}_{2}$, and $\mathrm{CO}$ EFs vs. MCE shown in Fig. 7. In particular, fires sampled during C134 may have had a larger smouldering component, and they appeared to have involved less complete combustion on average than in $\mathrm{C} 133$, which would explain the lower emissions of more highly oxidized $\mathrm{CO}_{2}$ and higher emissions of more reduced $\mathrm{CH}_{4}$ than were observed in $\mathrm{C} 134$.

The ratio of $\mathrm{HCN}$ enhancement to $\mathrm{HNCO}$ enhancement within the plumes is informative to quantify combustion completeness and in order to provide redundancy in estimating fire combustion efficiency. Molar ratios of $\mathrm{HCN}$ to $\mathrm{HNCO}$ in fire emissions have been shown to decrease linearly with increasing combustion temperature (Hansson et al., 2004). Hence lower $\Delta \mathrm{HCN} / \Delta \mathrm{HNCO}$ ratios should be expected from fires with more complete combustion. Figure 8a shows $\triangle \mathrm{HCN} / \triangle \mathrm{HNCO}$ decreasing linearly $\left(R^{2}=\right.$ 0.36 ) with increasing modified combustion efficiency for the MOYA-II fires. Consequently, Fig. 8b shows the methane emission factor decreasing with a lower $\Delta \mathrm{HCN} / \triangle \mathrm{HNCO}$ ratio. This further affirms that difference in combustion completeness is the primary driver of methane EF variability observed during MOYA-II. Unfortunately, a similar analysis could not be carried out for MOYA-I as the ToF-CIMS was not fitted to the aircraft during the MOYA-I flights.

As in flight $\mathrm{C} 132, \mathrm{~N}_{2} \mathrm{O}$ measurements for flight $\mathrm{C} 133$ were unreliable, and data were discarded due to the effects of aircraft motion on the instrument optical bench during turbulence. Furthermore, issues with the temperature control of the QCLAS optical bench meant that the baseline noise and drift 
(a)

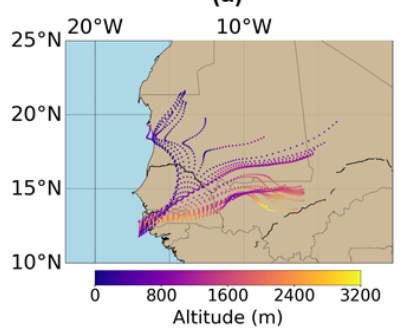

(c)

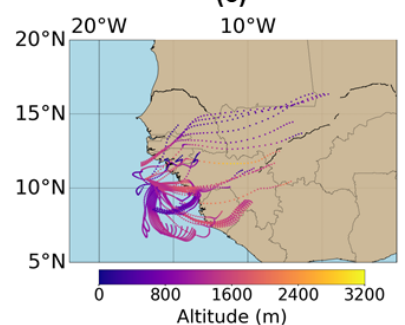

(b)

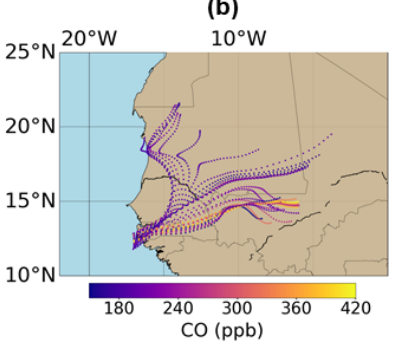

(d)

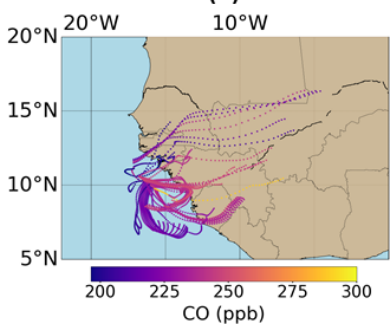

Figure 9. The $2 \mathrm{~d}$ HYSPLIT back trajectories from sections of the flight tracks of flights $\mathrm{C} 006$ and $\mathrm{C} 007$ during which biomass burning emissions were sampled (the in-fire-plume data from Fig. 10). The back trajectories are coloured by (a) trajectory altitude and (b) $\mathrm{CO}$ mixing ratio at the trajectory end point on the flight $\mathrm{C} 006$ flight track. Panels (c) and (d) show the back trajectories for flight C007, coloured by trajectory altitude and $\mathrm{CO}$ mixing ratio respectively. Trajectories are run at $60 \mathrm{~s}$ intervals of in-plume flight data. The base maps are obtained from Global Self-consistent, Hierarchical, High-resolution Geography Database (GSHHG) data (Wessel and Smith. 1996).

of the $\mathrm{N}_{2} \mathrm{O}$ signal increased during this flight. This resulted in a reduced signal-to-noise ratio of $\mathrm{N}_{2} \mathrm{O}$ in the plume. For these reasons, an $\mathrm{N}_{2} \mathrm{O} \mathrm{EF}$ is not reported for flight $\mathrm{C} 133$. However, optical bench temperature control was adequate during flight $\mathrm{C} 134$, and aircraft turbulence did not impact $\mathrm{N}_{2} \mathrm{O}$ data quality significantly during sampling of some fire plumes. Hence calculation of $\mathrm{N}_{2} \mathrm{O}$ EFs was possible for six of the nine fire plumes sampled during flight $\mathrm{C} 134$.

In general, the $\mathrm{N}_{2} \mathrm{O}$ mixing ratio enhancements in the fire plumes are small $(<10 \mathrm{ppb})$ relative to the background variability (and instrumental noise) of the $\mathrm{N}_{2} \mathrm{O}$ dataset (up to $2 \mathrm{ppb}$ ). Hence the signal-to-noise ratios of the in-plume $\mathrm{N}_{2} \mathrm{O}$ enhancements are poorer than the in-plume enhancements of other species. As a result of this, the uncertainty relative to the mean $\mathrm{N}_{2} \mathrm{O}$ EF for $\mathrm{C} 134$ is larger than those seen in the other species measured. Despite the combination of instrument issues and poor signal-to-noise ratio, the $\mathrm{N}_{2} \mathrm{O} \mathrm{EF}$ for flight $\mathrm{C} 134\left(0.08 \pm 0.01 \mathrm{~g} \mathrm{~kg}^{-1}\right)$ agrees within overlapping uncertainty with the savannah fire $\mathrm{N}_{2} \mathrm{O}$ EF reported by Andreae (2019) $\left(0.17 \pm 0.09 \mathrm{~g} \mathrm{~kg}^{-1}\right)$.

Figure 7 shows strong linear relationships between MCE and $\mathrm{CH}_{4}, \mathrm{CO}_{2}$, and $\mathrm{CO} \mathrm{EFs}$ for both MOYA-I and MOYA-II. There is no discernible linear relationship between the $\mathrm{N}_{2} \mathrm{O}$ EFs from C134 and MCE, which is shown in the Supplement in Fig. S5. It is worth noting that $\mathrm{CH}_{4} \mathrm{EFs}$ and correspond-

ing MCEs for the far-field flights C006 and C007 are not included in Fig. 7, as the EFs from these flights are representative of multiple fires with a mixture of phases, whereas the near-field EFs are representative of single fires with a single combustion efficiency associated with them. This trend is expected as higher MCEs, and hence more complete flaming combustion, would lead to increased emission of more oxidized combustion products $\left(\mathrm{CO}_{2}\right)$ and less emission of more reduced compounds such as $\mathrm{CH}_{4}$. Despite this, $\mathrm{CH}_{4} \mathrm{EFs}$ measured in Uganda appear to be significantly higher than those measured in Senegal at the same MCE; hence methane emissions from the Ugandan wildfires sampled appear to be higher, and this difference is independent of combustion efficiency. The difference in the linear regressions could possibly be accounted for by differences in the Senegalese and Ugandan fuel mixtures. However, due to detailed analysis of the fuel burned in this study being impossible, and with the likelihood of the fuel source being mixed, the effect of differing fuel content is difficult to quantify. An additional hypothesis is that higher average soil moisture in northern Uganda compared to south-west Senegal could result in soil parching and consequent release of methane-rich air from the soil surrounding wildfires; however more work is required to investigate whether soil moisture could affect wildfire methane EFs in this way.

\subsection{Far-field sampling}

Flights C006 and C007 were designed to characterize the regional continental outflow of air masses influenced by biomass burning from Senegal and wider West Africa. C006 and $\mathrm{C} 007$ involved sampling at various altitudes from 16 to 6500 ma.s.l. over the West African Atlantic coastline. C006 involved straight and level runs directly west of the Casamance region of Senegal targeted during the near-field flights $\mathrm{C} 004$ and $\mathrm{C} 005$. A strong measured easterly wind indicated continental outflow from the south-west Casamance region of Senegal during flight C006. Sampling during flight C007 was conducted further south, running parallel to the coastline of Guinea-Bissau due to the more complex meteorology encountered during the flight.

In order to identify the approximate origin and age of the biomass burning emissions sampled during the far-field flights, the National Oceanic and Atmospheric Administration (NOAA) HYbrid Single-Particle Lagrangian Integrated Trajectory (HYSPLIT) model was used to calculate threedimensional single-particle back trajectories of air masses sampled during C006 and C007 (Stein et al., 2015). HYSPLIT back trajectories were run at $60 \mathrm{~s}$ intervals during times where biomass burning emissions were sampled (Figs. S6 and S7 in the Supplement) The back trajectories for C006 shown in Fig. 9a and $b$ indicate that the age of the biomass burning plumes sampled was approximately $8 \mathrm{~h}$. Furthermore, the sampled air mass appeared to have advected over the south-western Casamance region, with the highest $\mathrm{CO}$ 

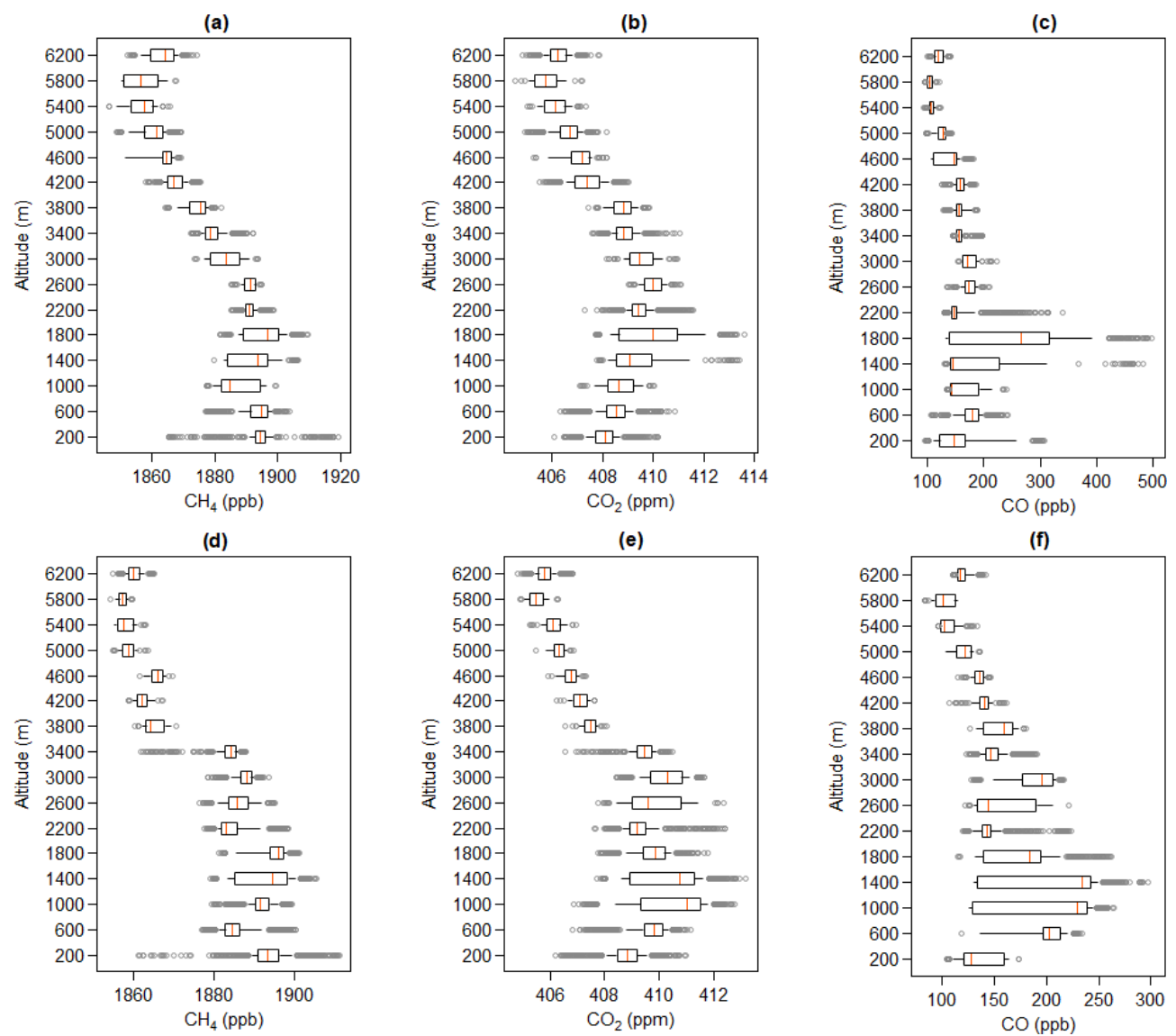

Figure 10. Box-whisker plots of (a) $\mathrm{CH}_{4}$, (b) $\mathrm{CO}_{2}$, and (c) $\mathrm{CO}$ altitude profiles for flight $\mathrm{C} 006$ and (d) $\mathrm{CH}_{4}$, (e) $\mathrm{CO}_{2}$, and (f) $\mathrm{CO}$ altitude profiles for flight C007. Altitude is divided into $400 \mathrm{~m}$ vertical bins for all box-whisker plots. The boxes represent the 25 th and 75 th percentiles, whiskers represent 10th and 90th percentiles, and the grey circular points are outliers.

concentrations observed in air masses that passed directly over this region. Thus, the sampled outflow represents a well-mixed air mass influenced by the fire regions targeted in the near field. The HYSPLIT back trajectories for C007 shown in Fig. 9c and d highlight the much more complex atmospheric dynamics influencing the sampled air masses during flight $\mathrm{C} 007$ as opposed to C006. The biomass burning emissions sampled during $\mathrm{C} 007$ originated from GuineaBissau, Guinea, Sierra Leone, and south-western Senegal, all of which were undergoing active burning during this time as shown in Fig. 1a. With these complex air masses, the approximate age of the biomass burning emissions observed in C007 was estimated to be older than that in C006, with an approximate age of 1-2 d. Consequently, the emissions sampled in $\mathrm{C} 007$ were representative of a wider area of West African biomass burning than C006, spanning from southwest Senegal down to Sierra Leone. Due to the significantly older plume age of the $\mathrm{C} 007$ biomass burning emissions, it is possible that significant chemical ageing and/or mixing of background air with plume air has occurred, and hence the ERs or EFs derived from this flight may not be representative of single source regions (see Sect. 2.6).
Box-whisker altitude profiles for flights $\mathrm{C} 006$ and $\mathrm{C} 007$ are shown in Fig. 10. Figure 10c shows peak CO concentrations in air masses at approximately $1600 \mathrm{~m}$ a.s.l. during flight C006. This is also consistent with fire plume injection heights observed during near-field sampling. Both $\mathrm{CH}_{4}$ and $\mathrm{CO}_{2}$ altitude profiles in Fig. 10a and b also show enhanced concentrations up to approximately 1600 ma.s.l., with a rapid decrease in mean CO concentration from $2000 \mathrm{~m}$ a.s.l., indicating free-tropospheric air above this. This was confirmed by analysis of measured thermodynamic profiles (not shown in this work). The altitude profiles in Fig. 10d-f show that during flight $\mathrm{C007}$, peak $\mathrm{CO}$ concentration as well as the highest mean $\mathrm{CO}$ concentration was measured at approximately 1400 ma.s.l. Concurrently, $\mathrm{CH}_{4}$, and $\mathrm{CO}_{2}$ mixing ratios were enhanced up to approximately $3400 \mathrm{~m}$ a.s.l. Above this, $\mathrm{CO}, \mathrm{CH}_{4}$ and $\mathrm{CO}_{2}$ mixing ratios decreased to background free-tropospheric concentrations with comparatively small ranges. In comparison to flight C006, in $\mathrm{C} 007$ the biomass burning emissions appeared to be more mixed throughout the polluted boundary layer.

A linear weighted regression was fitted to data points for $\mathrm{CH}_{4}$ and $\mathrm{CO}_{2}$ vs. tracer $\mathrm{CO}$ (Fig. 11) for samples within 

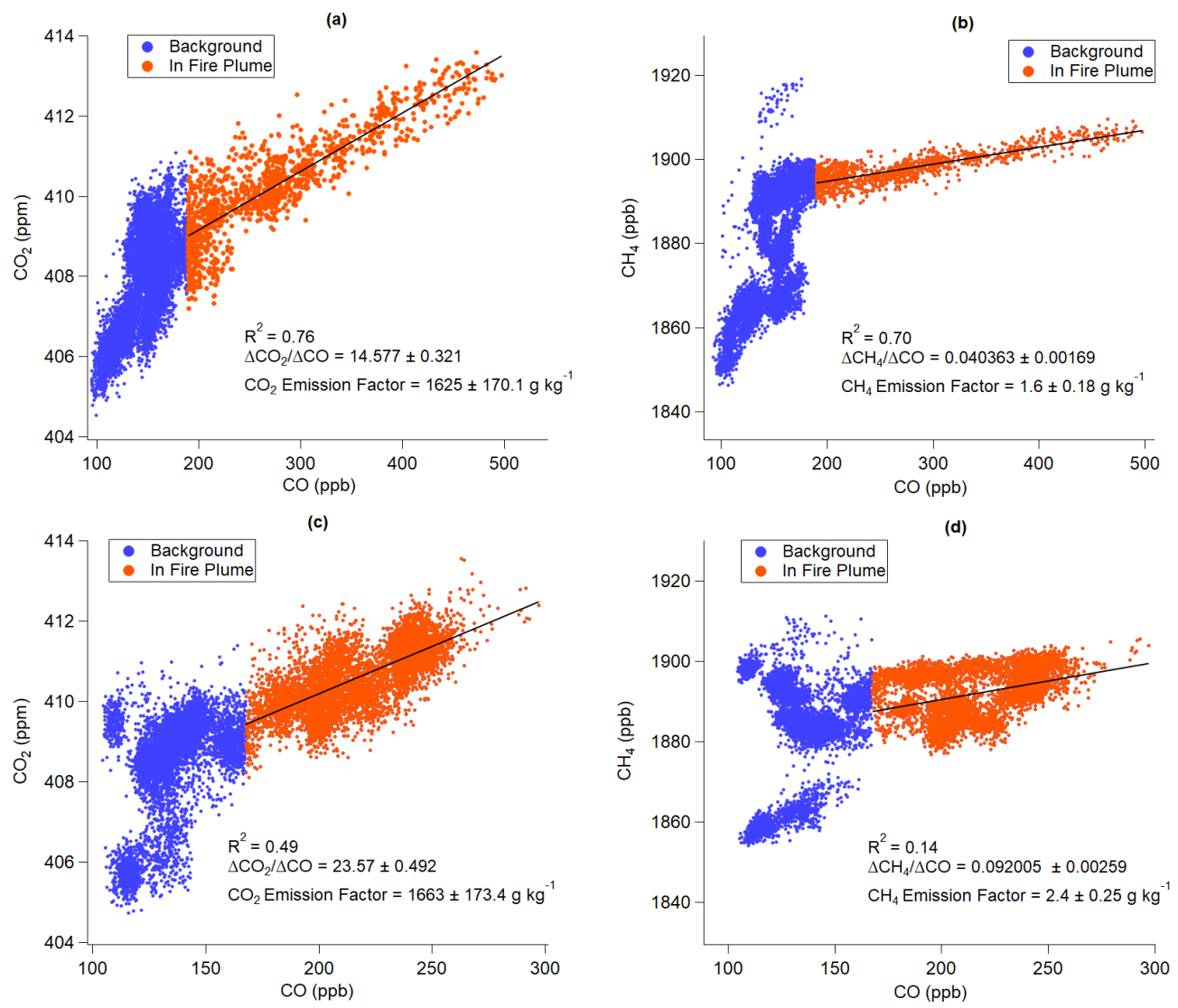

Figure 11. Linear regressions of in-plume (a) $\mathrm{CH}_{4}$ and (b) $\mathrm{CO}_{2}$ mixing ratio vs. in-plume $\mathrm{CO}$ mixing ratio for flight $\mathrm{C} 006$ and (c) $\mathrm{CH}_{4}$ and (d) $\mathrm{CO}_{2}$ mixing ratio vs. in-plume $\mathrm{CO}$ for flight $\mathrm{C} 007$. The linear regressions are calculated using the York regression method and are weighted towards $\mathrm{CO}$ and $\mathrm{CH}_{4} / \mathrm{CO}_{2}$ measurement uncertainty (York et al., 2004). ERs obtained from the slope are also shown, as well as the calculated EFs.

the biomass burning plume, using a statistical $\mathrm{CO}$ threshold to identify the smoke plumes from fires (as described in Sect. 2.6). The gradient of this fit was equivalent to the ERs with respect to $\mathrm{CO}$ and included in Table 1. Figure 11a and $\mathrm{b}$ show strong linear trends between in-plume $\mathrm{CH}_{4}$ and $\mathrm{CO}_{2}$ vs. $\mathrm{CO}$ for flight C006, with $R^{2}$ values of 0.70 and 0.76 respectively.

Although some degree of linearity is identifiable, the observed trends shown in Fig. 11c and d are significantly weaker than those seen for flight C006, with $R^{2}$ values of 0.14 for $\mathrm{CH}_{4}$ vs. $\mathrm{CO}$ and 0.49 for $\mathrm{CO}_{2}$ vs. $\mathrm{CO}$. The higher variance in the $\mathrm{C} 007$ linear regressions, when compared with $\mathrm{C} 006$, could be attributed to mixed phases of burning and/or mixed degrees of chemical ageing present within the same biomass-burning-influenced air mass. Therefore homogenization of species from individual fire areas within the whole enhanced plume in $\mathrm{C} 007$ may be incomplete, and multiple fire phases with distinct combustion efficiencies or plume ageing may explain the poorer fits seen in $\mathrm{C} 007$.

As observed in Sect. 3.1 in the near-field sampling flights C004 and C005, the methane EF calculated for C006 (1.6 \pm $\left.0.18 \mathrm{~g} \mathrm{~kg}^{-1}\right)$ and $\mathrm{C} 007\left(2.4 \pm 0.25 \mathrm{~g} \mathrm{~kg}^{-1}\right)$ is more compa- rable to savannah and grassland burning methane EF (2.7 \pm $2.2 \mathrm{~g} \mathrm{~kg}^{-1}$ ) reported by Andreae (2019). This is attributed to the mixed nature of the fuel source, likely comprised of facultatively deciduous forest litter and savannah grasses

MCE values of $0.94 \pm 0.0041$ for C006 and $0.96 \pm 0.0037$ for $\mathrm{C} 007$ are also shown in Table 1. It is likely that biomass burning signatures with a higher smouldering component were sampled in $\mathrm{C006}$, which is further evidenced by the lower $\mathrm{CO}_{2} \mathrm{EFs}$ determined for $\mathrm{C} 006$. In contrast, the $\mathrm{CH}_{4}$ $\mathrm{EF}$ is higher for $\mathrm{C007}$, in which more complete combustion is inferred from the MCE. It is expected that this is due to the ageing of species sampled offshore in a recirculated air mass in C007 (as shown Fig. 12) and hence an indication that ERs and EFs may not be representative of the source fires. Despite ERs and EFs being shown for C007 in Fig. 11c and d, the EFs for $\mathrm{C} 007$ are not included in the mean calculation for Senegalese biomass burning EFs. 


\section{Conclusions}

Airborne observations of $\mathrm{CH}_{4}, \mathrm{CO}_{2}$, and $\mathrm{CO}$ emissions from biomass burning were carried out in southern Senegal in February-March 2017 and northern Uganda in January 2019. Mean EFs of $1.8 \pm 0.19 \mathrm{~g} \mathrm{~kg}^{-1}$ for $\mathrm{CH}_{4}, 1633 \pm 171.4 \mathrm{~g} \mathrm{~kg}^{-1}$ for $\mathrm{CO}_{2}$, and $67 \pm 7.4 \mathrm{~g} \mathrm{~kg}^{-1}$ for $\mathrm{CO}$ were obtained from the Senegalese fires, with a mean modified combustion efficiency of $0.94 \pm 0.005$. Mean EFs of $3.1 \pm 0.35 \mathrm{~g} \mathrm{~kg}^{-1}$ for $\mathrm{CH}_{4}, 1610 \pm 169.7 \mathrm{~g} \mathrm{~kg}^{-1}$ for $\mathrm{CO}_{2}$, and $78 \pm 8.9 \mathrm{~g} \mathrm{~kg}^{-1}$ for $\mathrm{CO}$ were obtained for the Ugandan fires, with a mean modified combustion efficiency of $0.93 \pm 0.004$. A mean $\mathrm{N}_{2} \mathrm{O}$ $\mathrm{EF}$ of $0.08 \pm 0.01 \mathrm{~g} \mathrm{~kg}^{-1}$ is also reported for six fire plumes sampled over Uganda. $\mathrm{CH}_{4}$ EFs showed strong linear relationships with modified combustion efficiency for both Senegal and Uganda. The variability in EFs within each study area was attributed to the mixed-phase nature of the fires, with a range of combustion efficiencies observed. These results also suggest that Ugandan fires have a higher methane emission factor for the equivalent combustion efficiency observed for Senegal. This may be a consequence of the difference in fuel between the Ugandan savannah grass and cropland waste fuels and the Senegalese forest litter and grassland fuel. This highlights the importance of considering both regional and local variability when attempting to spatially scale biomass burning emissions and suggests that singular regional EF values may lead to inaccurate estimates. Further work to constrain EFs at more local scales and for more specific (and quantifiable) fuel types will serve to improve global estimates of biomass burning emissions of climate-relevant gases.

This work demonstrates the value of airborne measurements for characterizing biomass burning emissions from multiple fires over wide areas. This study has provided unique in situ datasets in two geographical regions where there has hitherto been little study by aircraft measurement. The results will improve understanding of the role of African biomass burning in the global carbon budget, and the work demonstrates the importance of good knowledge of fuel mixture for the accurate reporting of EFs. This study demonstrates the utility of airborne measurements for characterizing biomass burning emissions from multiple fires over wide areas. Further work is required to investigate the link that fire fuel content may have on the emission of methane from biomass burning.

Data availability. FAAM ARA data from the MOYA project can be found on the CEDA archive at https://catalogue.ceda.ac.uk/uuid/ d309a5ab60b04b6c82eca6d006350ae6 (FAAM, NERC, Met Office, 2017).

Supplement. The supplement related to this article is available online at: https://doi.org/10.5194/acp-20-15443-2020-supplement.
Author contributions. PAB was the lead author, with writing contributions from GA, SJ-BB, REF, and TB. The flight methodology was devised by GA, EGN, JDL, and KNB. The paper methodology was designed by PAB, GA, JRP, and HC. Measurements aboard the aircraft were taken by PAB, JRP, REF, TB, SJ-BB, DP, SC, MBS, and $A M$. Data curation and validation were undertaken by $\mathrm{PAB}$, JRP, REF, TB, SJ-BB, DP, and SC with input from CJP and HC. Review of the draft manuscript was undertaken by all co-authors. Funding was acquired by EGN, GA, and JDL.

Competing interests. The authors declare no conflict of interest.

Acknowledgements. The data used in this publication have been collected as part of the Methane Observations and Yearly Assessments (MOYA) project funded by the Natural Environment Research Council (NERC) (The Global Methane Budget, University of Manchester reference: NE/N015835/1 Royal Holloway, University of London reference: NE/N016211/1). Airborne data were obtained using the BAe-146-301 Atmospheric Research Aircraft (ARA) flown by Airtask Ltd and managed by FAAM Airborne Laboratory, jointly operated by UK Research and Innovation (UKRI) and the University of Leeds. We would like to give special thanks to the Airtask pilots and engineers and all staff at FAAM Airborne Laboratory for their hard work in helping plan and execute successful MOYA project flights. We acknowledge the use of MODIS data and imagery from LANCE FIRMS operated by NASA's Earth Science Data and Information System (ESDIS) with funding provided by NASA Headquarters (https://doi.org/10.5067/FIRMS/MODIS/MCD14DL.NRT.006).

The maps used in Figs. 1 and 5 are obtained from ArcGIS software (sources: Esri, HERE, Garmin, Intermap, Increment P Corp., GEBCO, USGS, FAO, NPS, NRCAN, GeoBase, IGN, Kadaster NL, Ordnance Survey, Esri Japan, METI, Esri China (Hong Kong). (C) OpenStreetMap contributors and the GIS user community). The maps used in Fig. 9 are produced using the Python Matplotlib Basemap package, using Global Self-consistent, Hierarchical, High-resolution Geography Database (GSHHG) coastline and border data (Wessel and Smith. 1996). P. A. Barker is in receipt of a PhD studentship as part of the NERC Earth, Atmosphere and Ocean Doctoral Training Partnership (EAO DTP) (NERC grant reference: NE/L002469/1).

Financial support. This research has been supported by the Natural Environment Research Council (grant no. NE/L002469/1, NEN015835/1 and NE/N016211/1).

Review statement. This paper was edited by Drew Gentner and reviewed by two anonymous referees.

\section{References}

Andreae, M. O.: Biomass burning: Its history, use and distribution and its impact on environmental quality and global climate, in: 
Global Biomass Burning: Atmospheric, Climate and Biospheric Implications, edited by: Levine, J. S., MIT Press, Cambridge, MA, USA, 3-21, 1991.

Andreae, M. O.: Emission of trace gases and aerosols from biomass burning - an updated assessment, Atmos. Chem. Phys., 19, 8523-8546, https://doi.org/10.5194/acp-19-8523-2019, 2019.

Andreae, M. O. and Merlet, P.: Emission of trace gases and aerosols from biomass burning, Global Biogeochem. Cy., 15, 955-966, https://doi.org/10.1029/2000GB001382, 2001.

Bey, I., Jacob, D. J., Yantosca, R. M., Logan, J. A., Field, B. D., Fiore, A. M., Li, Q., Liu, H. Y., Mickley, L. J., and Schultz, M. G.: Global modeling of tropospheric chemistry with assimilated meteorology: Model description and evaluation, J. Geophys. Res.-Atmos., 106, 23073-23095, https://doi.org/10.1029/2001JD000807, 2001.

Brownlow, R., Lowry, D., Fisher, R. E., France, J. L., Lanoisellé, M., White, B., Wooster, M. J., Zhang, T., and Nisbet, E. G.: Isotopic Ratios of Tropical Methane Emissions by Atmospheric Measurement, Global Biogeochem. Cy., 31, 14081419, https://doi.org/10.1002/2017GB005689, 2017.

Buchhorn, M., Smets, B., Bertels, L., Lesiv, M., Tsendbazar, N.E., and Li, L.: Copernicus Global Land Service: Land Cover $100 \mathrm{~m}$, epoch 2018, Africa Demo (Version V2.1.1), https://doi.org/10.5281/zenodo.3518087, 2019.

Chanton, J. P., Rutkowski, C. M., Schwartz, C. C., Ward, D. E., and Boring, L.: Factors influencing the stable carbon isotopic signature of methane from combustion and biomass burning, J. Geophys. Res.-Atmos., 105, 1867-1877, https://doi.org/10.1029/1999JD900909, 2000.

Ciais, P., Sabine, C., Bala, G., Bopp, L., Brovkin, V., Canadell, J., Chhabra, A., DeFries, R., Galloway, J., Heimann, M., Jones, C., Quéré, C. Le, Myneni, R. B., Piao, S., and Thornton, P.: The physical science basis. Contribution of working group I to the fifth assessment report of the intergovernmental panel on climate change, Chang. IPCC Clim., Cambridge University Press, Cambridge, United Kingdom and New York, NY, USA, 465-570, https://doi.org/10.1017/CBO9781107415324.015, 2013.

Cofer, W., Levine, J., Winstead, E., Cahoon, D., Sebacher, D., Pinto, J., and Stocks, B.: Source compositions of trace gases released during African savanna fires, J. Geophys. Res.-Atmos., 101, 23597-23602, 1996.

Crutzen, P. J. and Andreae, M. O.: Biomass Burning in the Tropics: Impact on Atmospheric Chemistry and Biogeochemical Cycles, in: Paul J. Crutzen: A Pioneer on Atmospheric Chemistry and Climate Change in the Anthropocene, edited by: Crutzen, P. J. and Brauch, H. G., Springer International Publishing, Cham., 165-188, 2016.

De Wolf, J.: Species composition and structure of the woody vegetation of the Middle Casamance region (Senegal), Forest Ecol. Manag., 111, 249-264, 1998.

Dlugokencky, E. J., Nisbet, E. G., Fisher, R., and Lowry, D.: Global atmospheric methane: Budget, changes and dangers, Philos. T. R. Soc. A, 369, 2058-2072, https://doi.org/10.1098/rsta.2010.0341, 2011

Ehhalt, D. and Prather, M.: Atmospheric Chemistry and Greenhouse Gases, Clim. Chang. 2001 Sci. Basis, Pacific Northwest National Lab. (PNNL), Richland, WA, USA, 239-287, https://doi.org/10.2753/JES1097-203X330403, 2001.
Facility for Airborne Atmospheric Measurements: Natural Environment Research Council; Met Office: MOYA: ground station and in-situ airborne observations by the FAAM BAE-146 aircraft. Centre for Environmental Data Analysis, available at: http://catalogue.ceda.ac.uk/uuid/ d309a5ab60b04b6c82eca6d006350ae6 (last access: March 2019), 2017.

FEWS NET: Uganda, available at: https://fews.net/east-africa/ uganda, last access: 25 March 2020.

Fisher, R., Lowry, D., Wilkin, O., Sriskantharajah, S., and Nisbet, E. G.: High-precision, automated stable isotope analysis of atmospheric methane and carbon dioxide using continuous-flow isotope-ratio mass spectrometry, Rapid Commun. Mass Sp., 20, 200-208, https://doi.org/10.1002/rcm.2300, 2006.

Frederiksen, P. and Lawesson, J. E.: Vegetation types and patterns in Senegal based on multivariate analysis of field and NOAAAVHRR satellite data, J. Veg. Sci., 3, 535-544, 1992.

Gatari, M. J. and Boman, J.: Black carbon and total carbon measurements at urban and rural sites in Kenya, East Africa, Atmos. Environ., 37, 1149-1154, https://doi.org/10.1016/S13522310(02)01001-4, 2003.

Gerbig, C., Schmitgen, S., Kley, D., Volz-Thomas, A., Dewey, K., and Haaks, D.: An improved fast-response vacuum-UV resonance fluorescence CO instrument, J. Geophys. Res.-Atmos., 104, 1699-1704, doi10.1029/1998JD100031, 1999.

Hansson, K. M., Samuelsson, J., Tullin, C. and Åmand, L. E.: Formation of $\mathrm{HNCO}, \mathrm{HCN}$, and $\mathrm{NH}_{3}$ from the pyrolysis of bark and nitrogen-containing model compounds, Combust. Flame, 137, 265-277, https://doi.org/10.1016/j.combustflame.2004.01.005, 2004.

Heimburger, A. M. F., Harvey, R. M., Shepson, P. B., Stirm, B. H., Gore, C., Turnbull, J., Cambaliza, M. O. L., Salmon, O. E., Kerlo, A. E. M., Lavoie, T. N., Davis, K. J., Lauvaux, T., Karion, A., Sweeney, C., Brewer, W. A., Hardesty, R. M., and Gurney, K. R.: Assessing the optimized precision of the aircraft mass balance method for measurement of urban greenhouse gas emission rates through averaging, Elementa, 5, 26, https://doi.org/10.1525/elementa.134, 2017.

Holmes, C. D., Prather, M. J., Søvde, O. A., and Myhre, G.: Future methane, hydroxyl, and their uncertainties: key climate and emission parameters for future predictions, Atmos. Chem. Phys., 13, 285-302, https://doi.org/10.5194/acp-13-285-2013, 2013.

Ichoku, C., Ellison, L. T., Willmot, K. E., Matsui, T., Dezfuli, A. K., Gatebe, C. K., Wang, J., Wilcox, E. M., Lee, J., Adegoke, J., and Okonkwo, C.: Biomass burning, land-cover change, and the hydrological cycle in Northern sub-Saharan Africa, Environ. Res. Lett., 11, 95005, https://doi.org/10:1088/17489326/11/9/095005, 2016.

Le Breton, M., Bacak, A., Muller, J. B. A., Bannan, T. J., Kennedy, O., Ouyang, B., Xiao, P., Bauguitte, S. J. B., Shallcross, D. E., Jones, R. L., Daniels, M. J. S., Ball, S. M., and Percival, C. J.: The first airborne comparison of $\mathrm{N}_{2} \mathrm{O}_{5}$ measurements over the UK using a CIMS and BBCEAS during the RONOCO campaign, Anal. Methods, 6, 9731-9743, https://doi.org/10.1039/c4ay02273d, 2014.

Lee, B. H., Lopez-Hilfiker, F. D., Veres, P. R., McDuffie, E. E., Fibiger, D. L., Sparks, T. L., and Iyer, S.: Flight deployment of a high-resolution time-of-flight chemical ionization mass spec- 
trometer: Observations of reactive halogen and nitrogen oxide species. J. Geophys. Res.-Atmos, 123, 7670-7686, 2018.

Li, Q., Jacob, D. J., Bey, I., Yantosca, R. M., Zhao, Y., Kondo, Y., and Notholt, J.: Atmospheric hydrogen cyanide (HCN): Biomass burning source, ocean sink?, Geophys. Res. Lett., 27, 357-360, 2000.

Li, Q., Jacob, D. J., Yantosca, R. M., Heald, C. L., Singh, H. B., Koike, M., Zhao, Y., Sachse, G. W., and Streets, D. G.: A global three-dimensional model analysis of the atmospheric budgets of $\mathrm{HCN}$ and $\mathrm{CH}_{3} \mathrm{CN}$ : Constraints from aircraft and ground measurements, J. Geophys. Res.-Atmos., 108, 8827, https://doi.org/10.1029/2002jd003075, 2003.

Liu, Y., Goodrick, S., and Heilman, W.: Wildland fire emissions, carbon, and climate: Wildfire-climate interactions, Forest Ecol. Manag., 317, 80-96, https://doi.org/10.1016/j.foreco.2013.02.020, 2014.

Montzka, S. A., Dlugokencky, E. J., and Butler, J. H.: Non-CO 2 greenhouse gases and climate change, Nature, 476, 43-50, https://doi.org/10.1038/nature10322, 2011.

Nisbet, E., Dlugokencky, E., Manning, M., Lowry, D., Fisher, R., France, J., Michel, S., Miller, J., White, J., Vaughn, B. and Bousquet, P.: Rising atmospheric methane: 2007-2014 growth and isotopic shift, Global Biogeochem. Cy., 30, 1356-1370, 2016.

Nisbet, E. G., Manning, M., Dlugokencky, E., Fisher, R., Lowry, D., Michel, S., and Brownlow, R. Very strong atmospheric methane growth in the 4 years 2014-2017: Implications for the Paris Agreement, Global Biogeochem. Cy., 33, 318-342, 2019.

O'Shea, S. J., Allen, G., Gallagher, M. W., Bauguitte, S. J.-B., Illingworth, S. M., Le Breton, M., Muller, J. B. A., Percival, C. J., Archibald, A. T., Oram, D. E., Parrington, M., Palmer, P. I., and Lewis, A. C.: Airborne observations of trace gases over boreal Canada during BORTAS: campaign climatology, air mass analysis and enhancement ratios, Atmos. Chem. Phys., 13, 1245112467, https://doi.org/10.5194/acp-13-12451-2013, 2013a.

O'Shea, S. J., Bauguitte, S. J.-B., Gallagher, M. W., Lowry, D., and Percival, C. J.: Development of a cavity-enhanced absorption spectrometer for airborne measurements of $\mathrm{CH}_{4}$ and $\mathrm{CO}_{2}$, Atmos. Meas. Tech., 6, 1095-1109, https://doi.org/10.5194/amt6-1095-2013, 2013b.

O’Shea, S. J., Allen, G., Fleming, Z. L., Bauguitte, S. J.-B., Percival, C. J., Gallagher, M. W., Lee, J., Helfter, C., and Nemitz, E.: Area fluxes of carbon dioxide, methane, and carbon monoxide derived from airborne measurements around Greater London: A case study during summer 2012, J. Geophys. Res.-Atmos., 119, 4940-4952, https://doi.org/10.1002/2013JD021269, 2014.

Pitt, J. R., Le Breton, M., Allen, G., Percival, C. J., Gallagher, M. W., J.-B. Bauguitte, S., O'Shea, S. J., Muller, J. B. A., Zahniser, M. S., Pyle, J., and Palmer, P. I.: The development and evaluation of airborne in situ $\mathrm{N}_{2} \mathrm{O}$ and $\mathrm{CH}_{4}$ sampling using a quantum cascade laser absorption spectrometer (QCLAS), Atmos. Meas. Tech., 9, 63-77, https://doi.org/10.5194/amt-9-63-2016, 2016.

Priestley, M., le Breton, M., Bannan, T. J., Worrall, S. D., Bacak, A., Smedley, A. R. D., Reyes-Villegas, E., Mehra, A., Allan, J., Webb, A. R., Shallcross, D. E., Coe, H., and Percival, C. J.: Observations of organic and inorganic chlorinated compounds and their contribution to chlorine radical concentrations in an urban environment in northern Europe during the wintertime, Atmos. Chem. Phys., 18, 13481-13493, https://doi.org/10.5194/acp-1813481-2018, 2018a.
Priestley, M., Le Breton, M., Bannan, T. J., Leather, K. E., Bacak, A., Reyes-Villegas, E., De Vocht, F., Shallcross, B. M. A., Brazier, T., Anwar Khan, M., Allan, J., Shallcross, D. E., Coe, H., and Percival, C. J.: Observations of Isocyanate, Amide, Nitrate, and Nitro Compounds From an Anthropogenic Biomass Burning Event Using a ToF-CIMS, J. Geophys. Res.-Atmos., 123, 76877704, https://doi.org/10.1002/2017JD027316, 2018 b.

Radke, L. F., Hegg, D. a, Hobbs, P. V, Nance, J. D., Lyons, J. H., Laursen, K. K., Weiss, R. E., Riggan, P. J., and Ward, D. E.: Particulate and Trace Gas Emissions from Large Biomass Fires in North America, in: Global Biomass Burning: Atmospheric, Climatic, and Biospheric Implications, edited by: Levine, J. S., MIT Press. Cambridge, MA, USA, 1991.

Saunois, M., Bousquet, P., Poulter, B., Peregon, A., Ciais, P., Canadell, J. G., Dlugokencky, E. J., Etiope, G., Bastviken, D., Houweling, S., Janssens-Maenhout, G., Tubiello, F. N., Castaldi, S., Jackson, R. B., Alexe, M., Arora, V. K., Beerling, D. J., Bergamaschi, P., Blake, D. R., Brailsford, G., Brovkin, V., Bruhwiler, L., Crevoisier, C., Crill, P., Covey, K., Curry, C., Frankenberg, C., Gedney, N., Höglund-Isaksson, L., Ishizawa, M., Ito, A., Joos, F., Kim, H.-S., Kleinen, T., Krummel, P., Lamarque, J.-F., Langenfelds, R., Locatelli, R., Machida, T., Maksyutov, S., McDonald, K. C., Marshall, J., Melton, J. R., Morino, I., Naik, V., O’Doherty, S., Parmentier, F.J. W., Patra, P. K., Peng, C., Peng, S., Peters, G. P., Pison, I., Prigent, C., Prinn, R., Ramonet, M., Riley, W. J., Saito, M., Santini, M., Schroeder, R., Simpson, I. J., Spahni, R., Steele, P., Takizawa, A., Thornton, B. F., Tian, H., Tohjima, Y., Viovy, N., Voulgarakis, A., van Weele, M., van der Werf, G. R., Weiss, R., Wiedinmyer, C., Wilton, D. J., Wiltshire, A., Worthy, D., Wunch, D., Xu, X., Yoshida, Y., Zhang, B., Zhang, Z., and Zhu, Q.: The global methane budget 2000-2012, Earth Syst. Sci. Data, 8, 697751, https://doi.org/10.5194/essd-8-697-2016, 2016.

Schaefer, H.: On the Causes and Consequences of Recent Trends in Atmospheric Methane, Curr. Clim. Change Rep., 5, 259-274, https://doi.org/10.1007/s40641-019-00140-z, 2019.

Stein, A. F., Draxler, R. R., Rolph, G. D., Stunder, B. J. B., Cohen, M. D., and Ngan, F.: Noaa's hysplit atmospheric transport and dispersion modeling system, B. Am. Meteorol. Soc., 96, 2059-2077, https://doi.org/10.1175/BAMS-D-14-00110.1, 2015.

Turner, A. J., Frankenberg, C., and Kort, E. A.: Interpreting contemporary trends in atmospheric methane, P. Natl. Acad. Sci. USA, 116, 2805-2813, https://doi.org/10.1073/pnas.1814297116, 2019.

Urbanski, S.: Combustion efficiency and emission factors for wildfire-season fires in mixed conifer forests of the northern Rocky Mountains, US, Atmos. Chem. Phys., 13, 7241-7262, https://doi.org/10.1016/j.foreco.2013.05.045, 2013.

van der Werf, G. R., Randerson, J. T., Giglio, L., Collatz, G. J., Mu, M., Kasibhatla, P. S., Morton, D. C., DeFries, R. S., Jin, Y., and van Leeuwen, T. T.: Global fire emissions and the contribution of deforestation, savanna, forest, agricultural, and peat fires (1997-2009), Atmos. Chem. Phys., 10, 11707-11735, https://doi.org/10.5194/acp-10-11707-2010, 2010.

Ward, D. E. and Hardy, C. C.: Advances in the characterization and contril of emissions from prescribed fires, in: Proceedings, Annual Meeting - Air Pollution Control Association, San Francisco, CA, USA, 24-29 June, 1984. 
Ward, D. E. and Radke, L. F.: Emissions Measurements from Vegetation Fires?: A Comparative Evaluation of Methods and Results, in: Fire Environ. Ecol. Atmos. Clim. Importance Veg. Fires, John Wiley \& Sons, Chichester, England, 53-76, 1993.

Ward, D. E., Hao, W. M., Susott, R. A., Babbitt, R. E., Shea, R. W., Kauffman, J. B., and Justice, C. O.: Effect of fuel composition on combustion efficiency and emission factors for African savanna ecosystems, J. Geophys. Res.-Atmos., 101, 23569-23576, https://doi.org/10.1029/95jd02595, 1996.

Wessel, P. and Smith, W. H. F.: A global, self-consistent, hierarchical, high-resolution shoreline database, J. Geophys. Res.-Sol. Ea., 101, 8741-8743, https://doi.org/10.1029/96jb00104, 1996.

Yokelson, R., Goode, J., Ward, D., Susott, R., Babbitt, R., Wade, D., Bertschi, I., Griffith, D., and Hao, W.: Emissions of formaldehyde, acetic acid, methanol, and other trace gases from biomass fires in North Carolina measured by airborne Fourier transform infrared spectroscopy, J. Geophys. Res.-Atmos., 104, 30109_ 30125, 1999.
Yokelson, R. J., Crounse, J. D., DeCarlo, P. F., Karl, T., Urbanski, S., Atlas, E., Campos, T., Shinozuka, Y., Kapustin, V., Clarke, A. D., Weinheimer, A., Knapp, D. J., Montzka, D. D., Holloway, J., Weibring, P., Flocke, F., Zheng, W., Toohey, D., Wennberg, P. O., Wiedinmyer, C., Mauldin, L., Fried, A., Richter, D., Walega, J., Jimenez, J. L., Adachi, K., Buseck, P. R., Hall, S. R., and Shetter, R.: Emissions from biomass burning in the Yucatan, Atmos. Chem. Phys., 9, 5785-5812, https://doi.org/10.5194/acp-9-57852009, 2009.

Yokelson, R. J., Andreae, M. O., and Akagi, S. K.: Pitfalls with the use of enhancement ratios or normalized excess mixing ratios measured in plumes to characterize pollution sources and aging, Atmos. Meas. Tech., 6, 2155-2158, https://doi.org/10.5194/amt6-2155-2013, 2013.

York, D., Evensen, N. M., Martìnez, M. L., and De Basabe Delgado, J.: Unified equations for the slope, intercept, and standard errors of the best straight line, Am. J. Phys., 72, 367-375, https://doi.org/10.1119/1.1632486, 2004. 